\author{
Universidade de São Paulo \\ Instituto de Física \\ Instituto de Química \\ Instituto de Biociências \\ Faculdade de Educação
}

\title{
Formulação, aplicação e avaliação de exercícios operatórios como procedimento para auxiliar o aprendizado de conceitos de química
}

\section{Ricardo Eidi Honda}

Orientador: Prof. Dr. Bayardo B. Torres

Dissertação de mestrado apresentada ao Instituto de Física, ao Instituto de Química, ao Instituto de Biociências e a Faculdade de Educação da Universidade de São Paulo, para a obtenção do título de Mestre em Ensino de Ciências. 


\section{Ricardo Eidi Honda}

\section{Formulação, aplicação e avaliação de exercícios operatórios como procedimento para auxiliar o aprendizado de conceitos de química}

Área de concentração: ensino de química

Orientador: Prof. Dr. Bayardo B. Torres

Dissertação de mestrado apresentada ao Instituto de Física, ao Instituto de Química, ao Instituto de Biociências e a Faculdade de Educação da Universidade de São Paulo, para a obtenção do título de Mestre em Ensino de Ciências.

Banca Examinadora:

Prof $^{\circ}$ Dr. Bayardo B. Torres (IQ-USP)

Prof ${ }^{a}$ Dra. Adelaide Faljoni-Alario (UFABC)

Prof $^{\circ}$ Dr. Guilherme Andrade Marson (IQ-USP)

São Paulo

2011 
FICHA CATALOGRÁFICA

Preparada pelo Serviço de Biblioteca e Informação do Instituto de Física da Universidade de São Paulo

Honda, Ricardo Eidi

Formulação, aplicação e avaliação de exercícios operatórios como procedimento para auxiliar o aprendizado de conceitos de química - São Paulo, 2011.

Dissertação (Mestrado) - Universidade de São Paulo. Faculdade de Educação, Instituto de Física, Instituto de Química e Instituto de Biociências.

Orientador: Prof. Dr. Bayardo B. Torres

Área de Concentração: Ensino de Ciências

Unitermos: 1. Ensino; 2. Química; 3. Avaliação da Aprendizagem; 4. Formação de Conceito; 5 . Experimentos Científicos.

USP/IF/SBI-006/2011 
"Não há educador tão sábio que nada possa aprender, nem educando tão ignorante que nada possa ensinar".

Fernando Becker Professor Titular da Universidade Federal do Rio Grande do Sul 
Aos meus pais, Antonio e Hiroko, e à minha querida companheira Luciana, que sempre me incentivaram a alcançar meus objetivos. 


\section{AGRADECIMENTOS}

Um trabalho acadêmico sempre envolve a participação de pessoas e de instituições que, de diversas maneiras, nos ajudam a atingir nossos objetivos. Meus sinceros agradecimentos:

$>\quad$ Aos meus familiares, por terem acreditado em mim em todos os momentos, em especial aos meus pais, Antonio e Hiroko, que, mesmo com muitas dificuldades, fizeram com que eu tivesse uma boa formação acadêmica e humildade para ter chegado até aqui.

$>\quad$ À minha segunda-mãe, minha tia Mitiko, que trocou minhas fraldas e, desde então, me acompanha nesta longa jornada da vida.

$>\quad$ À minha querida companheira Luciana, pelo apoio e atenção concedidos todos os dias.

$>$ Ao meu orientador Prof. Dr. Bayardo B. Torres, por sua orientação, dedicação e compartilhamento de sua sabedoria e experiência na área de ensino.

> Ao professor Flávio Antonio Maximiano (IQ-USP) e à professora Roseli Cecília Rocha de Carvalho Baumel (FE-USP), por participarem da minha banca de qualificação com suas preciosas sugestões.

$>$ Aos meus colegas de trabalho, pessoas que possuem a minha admiração e respeito sempre e que fazem com que eu me sinta sempre feliz em exercer a profissão de professor.

$>$ Aos meus caros alunos, pelos ensinamentos dados e recebidos.

> À turma de 2002 do curso de Bacharelado e Licenciatura em Química do Instituto de Química da USP, pela amizade e companheirismo... difícil achar uma turma tão unida!!! E, é claro, a todos os amigos que fiz na universidade durante toda a minha vida acadêmica.

$>\quad$ À Universidade de São Paulo, que me proporcionou a oportunidade de buscar o conhecimento.

$>$ A todos aqueles que contribuíram direta ou indiretamente para a realização deste trabalho. 


\section{RESUMO}

HONDA, R. E., Formulação, aplicação e avaliação de exercícios operatórios como procedimento para auxiliar o aprendizado de conceitos de química. Dissertação (mestrado), Universidade de São Paulo, São Paulo, 2011.

Este trabalho relata uma investigação relacionada com o elo existente entre o processo de avaliação no ensino de Química e a aprendizagem de conceitos químicos por parte dos estudantes de Ensino Médio, tendo como metas principais: a análise de exercícios propostos em sala de aula ou em uma prova; o estudo de como tais exercícios são resolvidos pelos alunos; e a reconstrução da prática avaliativa segundo os momentos pedagógicos de Delizoicov (1991).

Além disso, foram propostos exercícios operatórios (RONCA E TERZI, 1995), em que o aluno se colocava como um agente resolvedor desses problemas. Tais exercícios operatórios foram aplicados com o intuito de averiguar se ocorreu uma aprendizagem significativa por parte dos alunos.

Pela análise dos dados obtidos, verificou-se que a estratégia utilizada apresentou resultados satisfatórios e os objetivos planejados foram atingidos.

Palavras-chave: exercícios operatórios, reconstrução da prática avaliativa, experimentos investigativos, Ronca e Terzi, Delizoicov. 


\section{ABSTRACT}

HONDA, R. E., Formulation, application and assessment of operative exercises as a procedure to help the learning of chemical concepts. Dissertation (Master's degree), University of São Paulo, São Paulo, 2011.

This research reports an investigation related to the existing bond between the assessment process in the Chemistry teaching and the learning of chemical concepts of high school students, having as main objectives: the analysis of proposed exercises in classroom or as a test; the study of how such exercises are solved by the students; and the reconstruction of assessment practice according to the pedagogic moments of Delizoicov (1991).

Also, operative exercises were proposed (RONCA and TERZI, 1995), where the student positioned himself as an solver agent of these problems. These operative exercises were applied with the objective of checking if a significant learning has or hasn't occurred from the students.

Through the analysis of obtained data, it was found that the strategy used showed satisfactory results and the planned objectives were reached.

Key-words: operative exercises, reconstruction of assessment practice, investigative experiments, Ronca and Terzi, Delizoicov. 


\section{SUMÁRIO}

INTRODUÇÃO

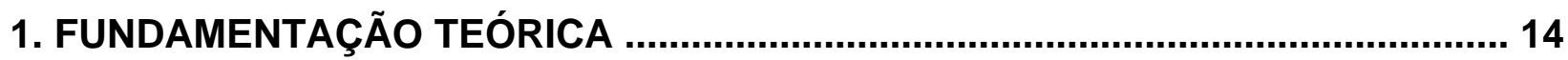

1.1 - O fenômeno "avaliação" .................................................................. 19

1.2 - Prática avaliativa x Aprendizagem significativa ..................................... 21

1.3 - Os marcos teóricos deste trabalho ...................................................... 25

1.3.1 - Paulo Afonso Caruso RONCA e Cleide do Amaral TERZI .......... 25

1.3.2 - Demetrio DELIZOICOV Neto ................................................... 27

1.4 - A importância dos experimentos investigativos ....................................... 31

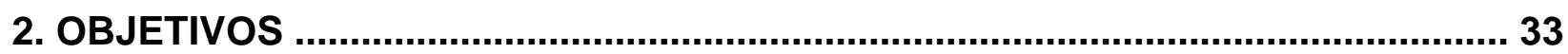

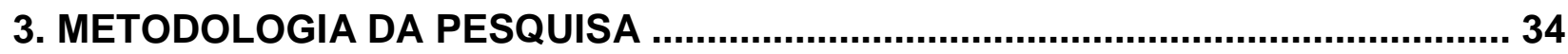

4. RESULTADOS E DISCUSSÃO

4.1 - Conteúdo: Separação de misturas (alunos do $1^{\circ}$ ano) …......................... 39

4.1.1 - Aplicação de exercícios não-operatórios e operatórios ............... 39

4.1.2 - A atividade experimental de caráter investigativo (reconstrução

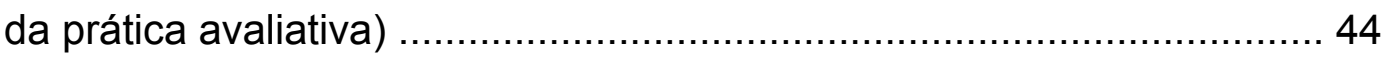

4.1.3 - Aplicação de exercícios operatórios após a reconstrução da

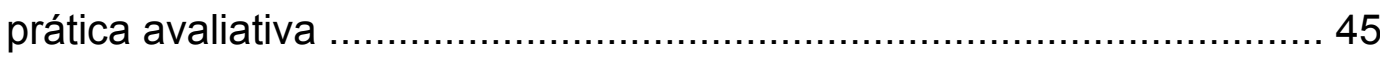

4.1.4 - Aplicação de novos exercícios operatórios na Etapa 5 ............... 49

4.2 - Conteúdo: Cinética Química (alunos do $2^{\circ}$ ano) ……….......................... 54

4.2.1 - Aplicação de exercícios não-operatórios e operatórios ............... 54

4.2.2 - A atividade experimental de caráter investigativo (reconstrução

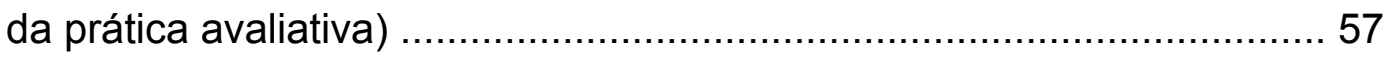

4.2.3 - Aplicação de exercícios operatórios após a reconstrução da

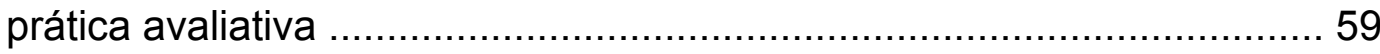

4.2.4 - Aplicação de novos exercícios operatórios na Etapa 5 ............... 62 
5. CONCLUSÕES E CONSIDERAÇÕES FINAIS

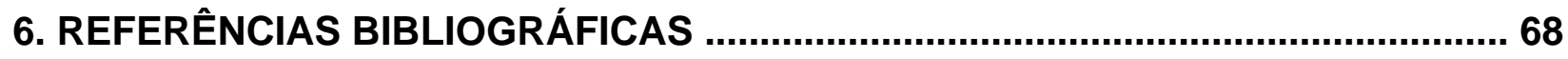

ANEXOS 


\section{INTRODUÇÃO}

Este trabalho relata uma investigação relacionada com o elo existente entre o processo de avaliação no ensino de Química e a aprendizagem de conceitos químicos por parte dos estudantes de Ensino Médio, tendo como metas principais a análise de exercícios propostos em sala de aula ou em uma prova e a reconstrução da prática avaliativa.

O interesse em estudar esse assunto foi motivado pela minha experiência como professor de Química do Ensino Médio, como ex-estagiário do curso de licenciatura e como ex-aluno de Ensino Médio e pela minha percepção de que muitos estudantes conseguem obter boas notas em Química sem que os conceitos químicos pertinentes estejam bem compreendidos.

Quando eu era aluno do Ensino Médio, percebi nitidamente que muitos estudantes memorizavam conceitos químicos, fórmulas, símbolos, etc e, sem compreenderem os conteúdos significativamente, tiravam boas notas. Quando ingressei no curso superior em Química (bacharelado e licenciatura) no Instituto de Química da Universidade de São Paulo, encontrei o mesmo problema.

Em 2005, fui contratado por um colégio renomado do município de São Bernardo do Campo para fazer um estágio (acompanhamento ao professor de Química em sala de aula). Tal colégio também possui na mesma sede, um curso preparatório para o vestibular, no qual fui plantonista de Química, ajudando alunos (do colégio e do curso preparatório para o vestibular) a tirarem dúvidas sobre exercícios. Nesta instituição, notei que muitos alunos do colégio que tiravam boas notas nas provas de Química, me 
procuravam para tirar dúvidas de exercícios mais complexos referentes àqueles conceitos que caíram em tais provas. Ao analisar algumas dessas provas de Química, percebi que existiam muitos exercícios que os alunos poderiam resolver através do uso de algoritmos ou através de uma simples memorização de conceitos. É importante ressaltar que o professor adotava uma postura classificatória, ou seja, corrigia as provas com a finalidade de aprovar ou reprovar, sem a intenção de orientar o aluno no seu crescimento humano, ou seja, não se via uma reconstrução da prática avaliativa. Assim, havia um princípio claro de descontinuidade: as notas, os conceitos, sem interpretação ou questionamento, tornavam-se obstáculos para a compreensão do erro construtivo. Naquele momento, perdia-se e descaracterizava-se a avaliação de seu significado básico de investigação e dinamização do processo de conhecimento.

Em meados de 2006, fui contratado por um colégio localizado no bairro Sumaré, município de São Paulo, para atuar como professor de Química, instituição de ensino na qual trabalho até hoje. Neste colégio, ajudei a introduzir uma disciplina (até então inexistente) no currículo do Ensino Médio: o Laboratório de Química. Foi nesse colégio que comecei efetivamente a minha carreira profissional como professor de Química. Desde que assumi o cargo de professor, venho tentando expressar resultados que possibilitem perceber os desempenhos dos alunos nas diversas atividades e áreas do conhecimento, além de sugerir ações para melhorar deficiências. Além disso, tenho procurado analisar as respostas dos alunos em sua dimensão de coerência, precisão, profundidade e criatividade na abordagem do tema.

Como professor desse colégio, comecei a me deparar com alguns problemas considerados comuns pela maioria dos professores: o estudo pela "nota" e a "cola". Os alunos parecem se interessar mais pelas notas que pela aprendizagem. Isso fica 
evidente através de algumas falas muito comuns: "É para nota?"; "Vai cair na prova?"; “Estudei tanto pra nada! Não caiu nada do que estudei! Que perda de tempo!". Ou seja, a prova é o centro de vida do estudante e só se estuda se tiver prova, só se estuda para a prova, só se estuda se cair na prova. Já a "cola" é outro problema corriqueiro nas escolas. Fiz a seguinte pergunta para alguns alunos (escolhi de forma aleatória) do Ensino Médio: "Na sua opinião, por que os alunos colam?". As respostas mais comuns foram: "Porque tem preguiça de estudar e sabem que outros alunos podem ajudar", "Porque eles ocupam o tempo com coisas inúteis e, para mostrar resultado aos pais, colam", "Porque eles se sentem inseguros pela prova ser algo importante para passar e acham que colando irão melhor que estudando".

Quando um aluno "cola", na verdade ele está realizando apenas a transcrição de algo que ele não memorizou. Ou seja, tirando os casos em que o aluno "cola" de outro aluno, um exercício que requer uma compreensão pertinente de um determinado conceito e que não dê para ser resolvido apenas por algoritmos ou memorização, pode amenizar esse problema.

Tendo em vista os pontos abordados acima, surgiu o interesse de desenvolver uma estratégia que possibilite um melhor entendimento dos conceitos químicos e verificar se tal procedimento ocasionou uma aprendizagem mais significativa por parte dos estudantes. Tal trabalho consistiu: na análise de exercícios aplicados em sala de aula ou em uma prova e no estudo de como tais exercícios são resolvidos pelos alunos; na reconstrução da prática avaliativa (tal conceito será tratado na seção 1.2) segundo os momentos pedagógicos de Delizoicov (1991) - no caso, através de experimentos investigativos; na aplicação de alguns exercícios operatórios (RONCA e TERZI, 1995), com o aluno atuando como um agente resolvedor desses problemas. Tais exercícios 
operatórios foram aplicados com o intuito de averiguar se ocorreu uma (maior) aprendizagem significativa (tal conceito também será tratado na seção 1.2) por parte dos alunos.

O trabalho está organizado na forma de capítulos. No primeiro capítulo, denominado Fundamentação teórica, apresenta-se uma revisão da literatura que serviu como um alicerce para a realização desta pesquisa, como estudos referentes à questão da avaliação, aos exercícios operatórios segundo Ronca e Terzi e aos momentos pedagógicos de Delizoicov, que irá auxiliar numa perspectiva construtivista defendida nesse trabalho. O segundo capítulo apresenta os objetivos que foram almejados para este trabalho juntamente com a hipótese levantada. O terceiro capítulo é dedicado aos aspectos metodológicos para a realização desta pesquisa, explicitando os instrumentos de coleta e a metodologia de análise. O quarto capítulo apresenta os resultados obtidos juntamente com a sua discussão. Por fim, no quinto capítulo, são apresentadas as conclusões e as considerações finais, seguida das referências bibliográficas utilizadas, constantes no sexto capítulo e dos anexos. 


\section{CAPÍTULO 1: FUNDAMENTAÇÃO TEÓRICA}

O Ensino Médio é fundamental para a formação intelectual e social do jovem. É nele que o aluno tem a chance de aprimorar conhecimentos, descobrir suas vocações, desenvolver as competências requeridas para tornar-se um ser social capaz de interagir com o seu meio de maneira responsável.

Para isso, há de se ter um embasamento nas diretrizes curriculares nacionais, aprovadas na década passada, que preveem um ensino através de assuntos de interesse coletivo, como educação ambiental, saúde e cidadania. Porém, o que se verifica, é que as escolas não aderiram à proposta; percebe-se que as escolas creem que a solução pode estar no aumento do número de disciplinas, quando se deve pensar mais na qualidade que na quantidade que se ensina.

O ensino estático e unidirecional é extremamente desmotivador para o aluno. A sala de aula não é apenas um lugar para transmitir conteúdos teóricos; é, também, local de aprendizado de valores e comportamentos, de aquisição de uma mentalidade científica lógica e participativa que poderá possibilitar ao aluno, bem orientado, interpretar e transformar a sociedade e natureza em benefício do bem-estar coletivo e pessoal.

O Artigo 205 da Constituição Federal (CF) de 1988 define como objetivos gerais da educação no país o "pleno desenvolvimento da pessoa, seu preparo para o exercício da cidadania e sua qualificação para o trabalho". Detalhando tal enunciado, o Art. 35 da

Lei de Diretrizes e Bases (LDB) de 1996 estabelece que o ensino médio brasileiro apresenta as seguintes finalidades: 
I. a consolidação e o aprofundamento dos conhecimentos adquiridos no ensino fundamental, possibilitando o prosseguimento dos estudos.

II. a preparação básica para o trabalho e a cidadania do educando, para continuar aprendendo, de modo a ser capaz de se adaptar com flexibilidade a novas condições de ocupação ou aperfeiçoamento posteriores.

III. o aprimoramento do educando como pessoa humana, incluindo a formação ética e o desenvolvimento da autonomia intelectual e do pensamento crítico.

IV. a compreensão dos fundamentos científico-tecnológicos dos processos produtivos, relacionando a teoria com a prática, no ensino de cada disciplina.

O aprendizado de Química no ensino médio "[...] deve possibilitar ao aluno a compreensão tanto dos processos químicos em si, quanto da construção de um conhecimento científico em estreita relação com as aplicações tecnológicas e suas implicações ambientais, sociais, políticas e econômicas". Dessa forma, os estudantes podem "[...] julgar com fundamentos as informações advindas da tradição cultural, da mídia e da própria escola e tomar decisões autonomamente, enquanto indivíduos e cidadãos" (PCNEM, 1999).

É preciso que o aluno perceba que a Química é importante porque ela está relacionada a tudo o que fazemos em nosso dia-a-dia, a tudo que somos, a tudo que consumimos, ao ambiente que nos cerca, à nossa história e que adquirir um conhecimento sólido dessa ciência é fundamental para o exercício pleno da cidadania, mesmo para uma pessoa que não pretenda fazer uma faculdade ou exercer uma profissão remunerada.

Essa ideia é reforçada pelos novos Parâmetros Curriculares Nacionais (os PCNs) definidos para o ensino médio, em que a Química faz parte das chamadas Ciências da 
Natureza, Matemática e suas Tecnologias e cujo objetivo final deve ser desenvolver as seguintes competências e habilidades:

\section{$\underline{\text { Representação e Comunicação }}$}

- Descrever as transformações químicas em linguagens discursivas.

- Compreender os códigos e símbolos próprios da Química atual.

- Traduzir a linguagem discursiva em linguagem simbólica da Química e vice-versa.

- Utilizar a representação simbólica das transformações químicas e reconhecer suas modificações ao longo do tempo.

- Traduzir a linguagem discursiva em outras linguagens usadas em Química: gráficos, tabelas e relações matemáticas.

- Identificar fontes de informação e formas de obter informações relevantes para o conhecimento da Química (livros, Internet, CD-ROM, jornais, manuais etc).

\section{$\underline{\text { Investigação e compreensão }}$}

- Compreender e utilizar conceitos químicos na visão macroscópica (lógico-empírica).

- Compreender os fatos químicos na visão macroscópica (lógico-formal).

- Compreender dados quantitativos, estimativas e medidas; compreender relações proporcionais presentes na Química (raciocínio proporcional).

- Reconhecer tendências e relações a partir de dados experimentais ou outras (classificação, seriação e correspondência em Química).

- Selecionar e utilizar ideias e procedimentos científicos (leis, teorias, modelos) para a resolução de problemas qualitativos e quantitativos em Química, identificando e acompanhando as variáveis relevantes. 
- Reconhecer ou propor a investigação de um problema relacionado à Química, selecionando procedimentos experimentais pertinentes.

- Desenvolver conexões hipotético-lógicas que possibilitem previsões acerca das transformações químicas.

\section{Contextualização sociocultural}

- Reconhecer aspectos químicos relevantes na interação individual e coletiva do ser humano com o ambiente.

- Reconhecer o papel da Química no sistema produtivo, industrial e rural.

- Reconhecer as relações entre o desenvolvimento científico e tecnológico da Química e os aspectos sócio-político-culturais.

- Reconhecer os limites éticos e morais que podem estar envolvidos no desenvolvimento da Química e da tecnologia.

O planejamento é essencial para um bom aprendizado e deve ser elaborado sem que se ignore as Diretrizes Curriculares para o Ensino Médio e, consequentemente, os PCNs, conforme descrito acima. Segundo o PCN de 2008, "o ensino de Química visa a contribuir para a formação da cidadania e, dessa forma, deve permitir o desenvolvimento de conhecimentos e valores que possam servir de instrumentos mediadores da interação do indivíduo com o mundo. Consegue-se isso mais efetivamente ao se contextualizar o aprendizado, o que pode ser feito com exemplos mais gerais, universais, ou com exemplos de relevância mais local, regional'.

Algumas questões para serem trabalhadas: como podemos avaliar se um aluno está realmente tendo uma aprendizagem significativa? Será que apenas uma prova é 
suficiente? Será que os exercícios propostos nos livros didáticos, em vestibulares e elaborados por professores auxiliam uma melhor avaliação do aluno? Será que, em determinados exercícios, o aluno acerta porque entendeu um conceito ou porque entendeu um algoritmo? Como deve agir o professor: como um transmissor de conteúdos ou como um mediador, um problematizador? Estas questões, entre muitas outras, levam-nos a refletir sobre o verdadeiro papel da escola: formar cidadãos.

Nos últimos tempos tem se falado muito no Brasil em Qualidade da Educação, já que pelos atuais indicadores de desempenho, nossos estudantes vão de mal a pior. Segundo os dados do relatório do PISA $^{1}$ (Programa Internacional de Avaliação de Alunos) do ano letivo de 2009, o desempenho do Brasil em Ciências não é bom. De 65 países participantes, o Brasil aparece na posição 53. O conhecimento dos alunos brasileiros em ciências é semelhante ao conhecimento dos alunos de países como Trinidad e Tobago, Colômbia, Montenegro, Argentina, Tunísia e Cazaquistão. Além disso, o Brasil está atrás de países latino-americanos como Chile, Uruguai e México (PISA, 2009).

\footnotetext{
${ }^{1}$ O PISA é um exame realizado a cada três anos pela OCDE (Organização para a Cooperação e o Desenvolvimento Econômico) e que busca medir o conhecimento e a habilidade em leitura, matemática e ciências de estudantes de 15 anos de idade tanto de países membros da OCDE quanto de países parceiros.
} 


\section{1 - O fenômeno "avaliação"}

O fenômeno avaliação é, hoje, um fenômeno indefinido. Usa-se o termo com diferentes significados relacionados à prática avaliativa tradicional: prova, nota, conceito, boletim, recuperação, reprovação. Dar nota é avaliar e o registro das notas denomina-se avaliação. Ao mesmo tempo, significados são atribuídos ao termo: análise de desempenho, julgamento de resultado. Decisões políticas encaminham a questão no sentido de eliminar das escolas o fenômeno da reprovação nas séries iniciais, procurando minimizar o prejuízo social decorrente da avaliação punitiva e obstaculizante ao projeto de vida de nossas crianças (HOFFMANN, 2003).

Eis que surge a questão: O que é avaliar?

A prática de que a avaliação era constituída de provas e exames teria origem nos séculos XVI e XVII. Segundo Perrenoud (1999), avaliar não é uma invenção tardia, nascida com os colégios por volta do século XVII e tornada indissociável do ensino de massa que conhecemos desde o século XIX, com a escolaridade obrigatória. Além disso, tal autor menciona que na avaliação os alunos são comparados e depois classificados em virtude de uma norma de excelência, definida no absoluto ou encarnada pelo professor e pelos melhores alunos.

Para Hoffmann (2003) a construção do ressignificado da avaliação pressupõe aos educadores um enfoque crítico da educação e do seu papel social. Já para Luckesi (1997) a avaliação se dá como um ato acolhedor, integrativo, inclusivo. Assim compreendendo sua colocação, é preciso distinguir a avaliação de julgamento, distinguir o certo do errado, que a base da avaliação seja acolher a situação, verificar sua qualidade e mudar se preciso for. 
É importante que haja uma análise de erros por parte dos alunos, não como uma desconsideração pelos acertos, mas para a compreensão das competências e limitações dos alunos e para a promoção da aprendizagem de Química.

Segundo Buriasco (2004), se a avaliação for conduzida com tal intuito, “(...) pode ser objeto de investigação (...), nessa perspectiva é necessário que os professores tomem ciência e consciência da importância da análise dos recursos e estratégias utilizados pelos alunos ao fazerem registros em questões de avaliação da produção didática".

Na perspectiva em reconstruir a prática avaliativa adotada em muitas escolas, parti do pressuposto de que a avaliação deixa de ser um ato de julgamento para potencializar o processo de construção do conhecimento, revelar os avanços e as suas necessidades para que sejam superadas. Ou seja, faz com que a avaliação propicie momentos de mudanças, avanços, progressos e, por fim, aprendizagem. Por fim, o processo de avaliação deve diagnosticar avanços e entraves, interferir, problematizar, questionar e redefinir novos rumos a serem percorridos. 


\section{2 - Prática avaliativa x Aprendizagem significativa}

Conforme relatado por Hoffmann (2003), avaliar e mensurar, muitas vezes, têm sido levados como sinônimos. Entretanto, segundo Hadji (1994), a medição traduz-se em números e a avaliação, em palavras.

Para Luckesi (1997), mensurar é sinônimo de verificar e não de avaliar, pois enquanto a verificação se limita à coleta e análise de informações sem consequências posteriores, a avaliação ultrapassa essa fronteira e conduz a uma ação.

De acordo com Ponte (1997), as práticas avaliativas, consideradas como tarefas que favoreçam aprendizagem, não podem estar vinculadas a um único momento ou forma de avaliar, do mesmo modo que somos injustos quando consideramos como algo inalterável um primeiro resultado seja individual ou coletivo.

Tal situação é complementada pelos estudos de Hadji (2001) ao abordar a cultura da avaliação formativa, ou seja, a avaliação como um elemento a serviço das aprendizagens, possibilitando compreender a situação do aluno, equacionando o seu desempenho, alimentado por indicações dadas pelo docente que façam o aluno prosseguir e não recrudescer.

Hadji (2001) destaca três momentos da avaliação em relação à ação de formação:

- a avaliação anterior à ação de formação, que objetiva um ajuste recíproco entre aluno e o currículo, ou seja, há uma preocupação em adequar a proposta de ensino à clientela escolar. É a chamada avaliação prognóstica;

- a avaliação pós-ação de formação, que significa a avaliação cumulativa, cuja intenção é verificar as aquisições ao final de um período. Utiliza recursos como a avaliação 
sócio-afetiva (atitude, valores, interesse, iniciativa), a autoavaliação, a participação (entrega de material, tarefas, etc.), trabalho em grupo (gestão coletiva de produção do conhecimento);

- a avaliação no centro da ação de formação, conhecida como avaliação formativa, que pretende atuar como reguladora da atividade do ensino. Está atenta ao ritmo, ao método de ensino, às estratégias, etc. Centra-se nas informações mais precisas, de ordem qualitativa, sobre os processos de aprendizagem do aluno.

Entretanto, sabe-se que estas ações são fragmentadas e, muitas vezes, misturadas de forma desequilibrada para atender às intenções educacionais de uma determinada instituição de ensino.

Este trabalho baseia-se na reconstrução da prática avaliativa que afeta tanto o aluno quanto o professor, o que significa alterar o reconhecimento do professor como o único responsável sobre o que o aluno consegue ou não produzir para uma dimensão que envolve regulações coletivas e individualizadas, com vistas a otimizar os itinerários de produção do conhecimento por parte do estudante. A avaliação, no centro do processo de formação, possibilita, ao aluno, a tomada de consciência das suas dificuldades e avanços, durante o processo de aprendizagem. Ao professor, esta abordagem favorece a flexibilização necessária para a modificação de sua ação pedagógica em função de aquisições efetivas dos alunos.

Esta abordagem, durante o processo de aprendizagem, inscreve a avaliação formativa na lógica da resolução de problemas, porque coloca, em cena, a especificidade de um ensino diferenciado. Na visão de Huberman apud Perrenoud (1999), a avaliação passa a concentrar-se na individualização das aprendizagens, na 
diferenciação das intervenções, nos meios pedagógicos, nas etapas e ritmos da aprendizagem e nos objetivos. Portanto, as práticas avaliativas homogeneizadoras, que focalizam apenas a quantificação, as atitudes e tudo que o aluno adquire, perdem o seu lugar. O que se quer é promover uma avaliação ao longo do processo de aprender, centrada no diálogo professor / aluno, com vistas à emancipação do sujeito e consequentemente, uma revisão das relações de poder que orientam a dinâmica escolar (ESTEBAN, 1999).

Para que as práticas avaliativas funcionem como uma maneira de gerar uma maior aprendizagem significativa por parte dos alunos é necessário que estes consigam se inserir em um processo no qual o conteúdo escolar a ser aprendido se ligue a outro já conhecido (AUSUBEL, 1982).

Ausubel et. al. (1980) defendem a ideia de que toda aprendizagem deve ser significativa, isto é, que o estudante relacione a nova informação a ser aprendida com o que já sabe, dando-lhe um lugar dentro de um todo mais amplo. Só assim, o estudante seria capaz de aplicar o que foi aprendido em determinada situação a uma variedade de situações semelhantes. Segundo eles, quanto mais significativo for o conteúdo aprendido, mais rápido será o processo de aprendizagem e quanto mais significativa for a aprendizagem, mais duradoura será a retenção na memória. Só será de fato aprendido aquilo que fizer sentido para o estudante, caso contrário ele irá reproduzir as informações nas avaliações e em seguida descartá-las.

Caso a aprendizagem significativa não ocorra, segundo o próprio Ausubel, temse uma aprendizagem mecânica em que as novas informações são aprendidas sem interagir com conceitos relevantes existentes na estrutura cognitiva, ou seja, o aluno decora fórmulas, leis e depois de um certo tempo, esquece. De acordo com Zoller 
(2002), tal aprendizagem mecânica se associa às habilidades cognitivas de baixa ordem (LOCS) ${ }^{2}$, caracterizadas por capacidades como: conhecer, recordar/relembrar a informação e/ou aplicar conhecimentos ou algoritmos memorizados na resolução de exercícios.

Segundo a teoria de Ausubel (1982), a aprendizagem significativa possui três vantagens essenciais em relação à aprendizagem mecânica. Em primeiro lugar, o conhecimento que se adquire de maneira significativa é retido e lembrado por mais tempo. Em segundo, aumenta a capacidade de aprender outros conteúdos de uma maneira mais fácil, mesmo se a informação original for esquecida. E, por fim, uma vez esquecida, facilita a aprendizagem seguinte - a "reaprendizagem", para dizer de outra maneira. A explicação dessas vantagens está nos processos específicos por meio dos quais se produz a aprendizagem significativa onde se implica, como um processo central, a interação entre a estrutura cognitiva prévia do aluno e o conteúdo de aprendizagem.

\footnotetext{
${ }^{2}$ LOCS: Lower Order Cognitive Skills (ZOLLER, 2002).
} 


\section{3 - Os marcos teóricos deste trabalho}

Como ter uma referência de objetivos educacionais a serem atingidos, ou em outras palavras, o quê, verdadeiramente, queremos atingir em educação? Para o desenvolvimento deste trabalho foram utilizados os conceitos expressos em dois marcos teóricos.

\subsection{1 - Paulo Afonso Caruso RONCA e Cleide do Amaral TERZI}

Quando se fala em exercícios operatórios, o termo operação é definido por Ronca e Terzi (1995), como uma ação mais elaborada e complexa, como, por exemplo: analisar, classificar, comparar, conceituar, criticar, generalizar e levantar hipóteses. Tais ações correspondem a operações intelectuais que requerem um alto nível de demanda cognitiva para a solução de um problema. Para Zoller (2002), são as habilidades cognitivas de alta ordem $(\mathrm{HOCS})^{3}$, caracterizadas por capacidades orientadas para a investigação, resolução de problemas, tomadas de decisões, desenvolvimento do pensamento crítico e avaliativo. As atividades experimentais de natureza investigativa (como as que foram abordadas neste trabalho) estão associadas ao desenvolvimento de habilidade de alta ordem.

Essas habilidades cognitivas de alta ordem (HOCS) correspondem às categorias mais altas da Taxonomia de Bloom ${ }^{4}$ (cognições de alta ordem, ou seja, análise, síntese e avaliação).

\footnotetext{
${ }^{3}$ HOCS: Higher Order Cognitive Skills (ZOLLER, 2002).

4 A Taxonomia de Bloom para os objetivos educacionais é uma representação hierárquica de seis processos cognitivos: conhecimento, compreensão, aplicação, análise, síntese e avaliação. Cada processo utiliza as capacidades adquiridas nos níveis anteriores. Conhecimento, compreensão e aplicação correspondem a cognições de baixa ordem; análise, síntese e avaliação correspondem a cognições de alta ordem.
} 
Para Ronca e Terzi (1995), os exercícios operatórios têm o grande mérito de romper com as clássicas maneiras de avaliar, bloqueando a dicotomia entre certo e errado. Esses exercícios têm a intenção de orientar passo a passo o aluno, deixando sempre explícitos os objetivos das questões que não são apresentadas de maneira isolada, fragmentada. As questões propiciam ao aluno que deixe de lado a memorização e comece a estabelecer relações com base em fatos, fenômenos, ideias, percebendo que nada disso ocorre isoladamente. Nos exercícios operatórios, os problemas devem ter relação direta com o conteúdo estudado, sendo que esse conteúdo não é um fim em si mesmo, mas uma ponte para pensar e para operar. Desta maneira, há uma grande distância entre decorar um conteúdo (por exemplo, quais são os nomes dos processos de separação de mistura) e compreender o significado desse conteúdo para a vida.

A grande maioria dos professores trabalha com a metodologia tradicional, centrada na simples transmissão do conhecimento, sendo o professor aquela figura que "sabe tudo", cuja função é "passar conteúdos", "vencer programas". Via de regra, as aulas são apenas expositivas e os livros didáticos são dogmaticamente utilizados. 0 aluno é treinado para memorizar e repetir os conteúdos que lhes forem transmitidos. Nesse tipo de ensino, não é levado em conta nem o que o aluno já sabe, nem suas experiências de vida. Desta forma, o que acontece é que o aluno decora conceitos quando estuda para as avaliações e, depois, esquece os conceitos científicos e permanece com as concepções alternativas que já possuía anteriormente.

O papel do professor não pode ser nem de um expositor nem de um facilitador, mas sim de um problematizador. Isso quer dizer que o professor deve ser um mediador, 
que coloca os alunos frente a situações problematizadoras, a partir das quais eles construirão seu próprio conhecimento.

Apesar das precárias condições de trabalho e salariais em que se encontram, os professores não devem aderir à indiferença pela profissão nem sentirem descompromissados com a educação. É preciso que tenham consciência da profissão que abraçaram e do papel que lhes cabe desempenhar, e que busquem enfrentar essa situação.

Portanto, é de fundamental importância que as metodologias tradicionais no ensino de química sejam repensadas pelos professores.

\subsection{2 - Demetrio DELIZOICOV Neto}

Uma alternativa ao ensino tradicional é encontrada na metodologia dos três momentos pedagógicos - Problematização Inicial (PI), Organização do Conhecimento (OC) e Aplicação do Conhecimento (AC) - conforme proposta por Delizoicov, detalhada mais adiante. Esta proposta é dialógica e contextualizada, permitindo uma muito significativa interação aluno-professor, e trabalhando o conhecimento científico a partir do que o aluno já sabe, das concepções que ele já detém, de suas vivências.

Segundo Freire (1987), o homem deve ser o sujeito da educação. Para que isso ocorra é imprescindível a interação homem-mundo, sujeito objeto, a fim de que o homem a desenvolva e se torne sujeito de fato. Para ele, a verdadeira educação é a problematizadora entendida como aquela através da qual é possível o crescimento mútuo entre professores e alunos, e o mútuo desenvolvimento da consciência crítica. 
De acordo com Becker (1993):

“(...) a educação problematizadora traz (...) 0 professor para a posição do aluno e o aluno para a posição do professor. (...) não há educador sábio que nada possa aprender, nem educando tão ignorante que nada possa ensinar (...)"

É importante o desafio cognitivo a que os alunos são submetidos quando o professor trabalha com a metodologia problematizadora, porque contribui para o enfrentamento de situações desafiadoras que se apresentam no seu cotidiano.

$\mathrm{Na}$ metodologia educacional dos três momentos pedagógicos segundo Delizoicov, está implícita uma proposta didático-pedagógica dialógica e problematizadora de educação, que fundamenta o presente trabalho. A dinamização dos conteúdos escolares, em sala de aula, é desenvolvida através dos assim chamados "momentos pedagógicos". Nessa dinâmica, as atividades educativas partem sempre da realidade do aluno, de seus conhecimentos e experiências, para que ele construa, a partir daí, o conhecimento novo, possibilitando-lhe adquirir consciência de sua situação existencial no meio onde vive. Nessa perspectiva, o trabalho do professor inicia pelo conhecer a realidade local na qual se inserem escola e alunos.

\section{Problematização inicial}

A problematização inicial inclui as seguintes etapas:

- Escolha do tema

- Apresentação de situações reais que os alunos conhecem e presenciam e que estão envolvidas nos temas 
- Exposição das ideias e pensamentos dos alunos

- Problematização do conhecimento que os alunos vão expondo, de modo geral, com base em poucas questões propostas relativas ao tema e às situações significativas

- Discussão das questões inicialmente discutidas num pequeno grupo, e depois com toda a classe, no grande grupo.

- O ponto culminante dessa problematização é fazer que o aluno sinta a necessidade da aquisição de outros conhecimentos que ainda não detém, ou seja, um problema que precisa ser enfrentado.

\section{Organização do conhecimento}

- Os conhecimentos selecionados como necessários para a compreensão dos temas e da problematização inicial são sistematicamente estudados neste momento, sob a orientação do professor.

- Variadas atividades são empregadas, de modo que o professor possa desenvolver a conceituação identificada como fundamental para uma compreensão científica das situações problematizadas.

- Resolução de problemas e exercícios, tais como os propostos em livros didáticos, pode desempenhar sua função formativa na apropriação de conhecimentos específicos.

\section{Aplicação do conhecimento}

- Analisar e interpretar tanto as situações iniciais que determinaram seu estudo como outras situações que, embora não estejam diretamente ligadas ao motivo inicial, podem ser compreendidas pelo mesmo conhecimento.

- Do mesmo modo que no momento anterior, as mais diversas atividades devem ser 
desenvolvidas, buscando a generalização da conceituação que já foi abordada.

- A meta pretendida com este momento é a de capacitar os alunos ao emprego dos conhecimentos, no intuito de formá-los para que articulem, constante e rotineiramente, a conceituação científica com situações reais.

- A identificação e o emprego da conceituação envolvida - ou seja, o suporte teórico fornecido pela ciência - é que estão em pauta neste momento.

A metodologia proposta por Delizoicov não faz referências à natureza das atividades das quais os conteúdos escolares selecionados são estudados por ocasião da Organização do Conhecimento. A Química é uma ciência experimental. Portanto, estudá-la sem a realização de atividades experimentais, pelo menos em algumas ocasiões, é totalmente desaconselhável: “(...) Sem experimentação, (...) a ciência é algo estático, livresco e sem desenvolvimento. (...) é apenas um arremedo de ensino, dogmático e sem atrativo, que afasta os alunos do estudo e compromete sua formação como cidadão (...)" (BELTRAN \& CISCATO, 1991, p.33). 


\section{4 - A importância dos experimentos investigativos}

Atualmente, a experimentação no ensino de ciências ainda é pouco utilizada nas escolas de nível médio (MALDANER, 2003) e muitas vezes, quando se tem essa prática, ela acontece de forma acrítica e aproblemática, sem a presença de um caráter investigativo, pouco contribuindo para a construção do conhecimento científico do aluno (MACHADO e MOL, 2008). Assim, para que as atividades experimentais desempenhem um importante papel no processo de ensino-aprendizagem, deve haver ação e reflexão.

As atividades experimentais, muitas vezes, não contemplam a relação teoriaprática, que é tratada como uma via de mão única, na qual a prática comprova a teoria ou vice versa (ZANON; SILVA, 2000). Atividades deste tipo, que privilegiam a ciência como verdade definitiva, estão apoiadas em concepções empírico-indutivista, e podem contribuir para a formação de um indivíduo com poucas argumentações, que reproduz somente o que lhe foi transmitido.

Quando se analisam livros didáticos de Química para o Ensino Médio, constatase uma inadequação dos roteiros experimentais sugeridos, pois estes geralmente aparecem no final dos capítulos do livro ou somente no guia do professor, sendo que, em sua grande maioria, nota-se a ausência de caráter investigativo (MACHADO e MOL, 2008).

Segundo Hodson (1996), é impossível o aluno descobrir algo que não está preparado para descobrir. Assim, o professor deve direcionar os alunos para a resolução do problema e os alunos devem elaborar hipóteses para a sua conclusão. As atividades experimentais devem ser preparadas considerando concepções prévias dos alunos e devem ser desenvolvidas na forma de problemas ou testagem de hipóteses. 
Tal perspectiva construtivista, segundo Ausubel (1982), aceita que nenhum conhecimento é assimilado do nada, mas deve ser (re)construído pela estrutura de conceitos já existentes.

Num experimento investigativo, a ação do aluno não deve se limitar apenas ao trabalho de manipulação ou observação. Tal experimento deve envolver reflexões, relatos, discussões, ponderações e explicações características de uma investigação científica (CARVALHO et al., 1999).

Watson et al. (1995) menciona que para o trabalho prático tornar-se eficaz na reconstrução da teoria pelo estudante, este precisa gastar mais tempo interagindo com suas ideias e menos tempo interagindo com aparatos. Ou seja, executar atividades experimentais que não privilegiam momentos de discussão, análise dos dados, elaboração de hipóteses, evidenciando somente o experimento em si, não contribui significativamente para o desenvolvimento de habilidades cognitivas pelos alunos.

Assim, para que o experimento investigativo seja mais significativo no processo de aprendizagem do estudante, deve haver ação e reflexão, ou seja, não basta apenas que os alunos executem o experimento, é necessário integrar a prática com discussão, análise dos dados obtidos e interpretação dos resultados, fazendo com que o aluno investigue o problema.

Para este trabalho, como uma forma de reconstruir a prática avaliativa, foram realizados dois experimentos de caráter investigativo que priorizassem os processos de coleta de dados, elaboração de hipóteses, análise, discussão dos resultados, estimulando a construção do conhecimento científico através da exploração de habilidades cognitivas (CARVALHO et. al., 1999). 


\section{CAPÍTULO 2: OBJETIVOS}

O objetivo deste trabalho é verificar se a aplicação de alguns exercícios pode indicar ou não uma aprendizagem significativa por parte dos alunos. Parte-se da hipótese de que alguns exercícios serão resolvidos facilmente pela grande maioria dos alunos, pois requerem apenas o conhecimento de um algoritmo ou uma simples memorização (habilidades cognitivas de baixa ordem - LOCS), mas que um percentual menor de alunos conseguirá responder exercícios operatórios (habilidades cognitivas de alta ordem - HOCS), conforme as ideias de Ronca e Terzi. Espera-se que esses alunos que não conseguiram responder tais exercícios operatórios, consigam fazê-lo após a reconstrução da prática avaliativa segundo os momentos de Delizoicov (utilizando a técnica da experimentação investigativa).

É interessante salientar que não há dados na literatura que fazem essa conexão entre ambos os marcos teóricos, mas julgo que isso seja pertinente, pois estará fazendo com que os alunos reconstruam o seu conhecimento a partir de seus erros.

O objetivo do trabalho é analisar se, após a reconstrução da prática avaliativa, os alunos que não conseguiam resolver os exercícios operatórios, passariam a resolvê-los.

Em resumo, os objetivos deste estudo são:

1. Analisar o grau de aprendizado dos estudantes através dos exercícios nãooperatórios e operatórios.

2. Aplicar o processo da reconstrução da prática avaliativa.

3. Avaliar a eficácia da intervenção, em particular aos alunos que apresentaram maiores dificuldades antes da reconstrução da prática avaliativa. 


\section{CAPÍTULO 3: METODOLOGIA DA PESQUISA}

O trabalho foi realizado com alunos do Ensino Médio de um colégio localizado na região de Sumaré, município de São Paulo, no qual sou o docente da disciplina de Química e o interventor deste trabalho. Trata-se de um estabelecimento da rede particular de ensino. Os sujeitos de pesquisa são os alunos do $1^{\circ}$ ano (35 alunos no total) e os alunos do $2^{\circ}$ ano (16 alunos no total). A faixa etária desses alunos é em torno de 15 - 17 anos e a proporção entre alunos e alunas é aproximadamente a mesma.

Para este trabalho, foram selecionados e analisados os seguintes conceitos / conteúdos: separação de misturas (com sujeitos do $1^{\circ}$ ano) e cinética química (com sujeitos do $2^{\circ}$ ano).

O método desse estudo trata de um procedimento para averiguar se alguns alunos conseguem aprender alguns conceitos de forma mais significativa após uma intervenção de minha parte. Parti do pressuposto de que um aluno só teria, a priori, atingido um nível cognitivo satisfatório, se tal sujeito conseguisse responder com clareza aos exercícios operatórios propostos, visto que tais exercícios, como relatado anteriormente, propiciam que o aluno deixe de lado a memorização e comece a estabelecer relações com base em fatos, ideias, fenômenos, percebendo que nada disso ocorre isoladamente. Ou seja, haveria assim ocorrido uma aprendizagem significativa, segundo os princípios de Ausubel (1982). Assim, os sujeitos que não

conseguiram responder aos exercícios operatórios propostos, mesmo após a intervenção (e mesmo conseguindo responder aos exercícios não operatórios - nesse 
caso, uma aprendizagem mecânica, segundo Ausubel), foram considerados como sujeitos que não obtiveram uma aprendizagem significativa.

Foram realizados os seguintes procedimentos de acordo com o Quadro I.

Quadro I - Procedimentos realizados neste trabalho.

\begin{tabular}{|l|c|}
\hline Etapa 1 & Aplicação de cinco exercícios não-operatórios. \\
\hline Etapa 2 & Aplicação de cinco exercícios operatórios. \\
\hline Etapa 3 & $\begin{array}{c}\text { Reconstrução da prática avaliativa - através de um experimento } \\
\text { investigativo. }\end{array}$ \\
\hline Etapa 4 & Aplicação de outros cinco exercícios operatórios. \\
\hline Etapa 5 & $\begin{array}{c}\text { Reaplicação dos cinco exercícios operatórios aplicados na Etapa 2 } \\
\text { após três meses da Etapa 4. }\end{array}$ \\
\hline
\end{tabular}

Etapa 1 - aplicação de cinco exercícios que, a princípio, podem ser respondidos através de uma simples memorização ou utilização de um algoritmo. A intenção era verificar se a grande maioria dos alunos consegue responder a esses tipos de exercícios. Alguns desses exercícios foram aplicados de forma objetiva (testes). Porém, nessas situações, foram aplicados quatro tipos de questionário, com tais exercícios iguais, porém com as alternativas embaralhadas. Essa atitude foi realizada com o intuito em amenizar o problema da "cola".

Etapa 2 - aplicação simultânea de cinco exercícios considerados como operatórios juntamente com os exercícios não-operatórios descritos na Etapa 1. A intenção era verificar se os alunos que conseguem responder a exercícios descritos na Etapa 1 
conseguem também responder a questões de ação mais elaborada e complexa, como, por exemplo: analisar, classificar, comparar, criticar, generalizar, levantar hipóteses.

Etapa 3 - reconstrução da prática avaliativa através de um experimento investigativo (organização do conhecimento, segundo Delizoicov). Esta reconstrução foi efetivada através da realização de alguns experimentos de caráter investigativo e da discussão dos mesmos. Os roteiros utilizados pelos alunos para esses experimentos estão localizados nos anexos deste trabalho. Atualmente, há vários dados na literatura que relatam os experimentos de caráter investigativo e a postura mediadora do professor (ROMANELLI, 1996; MATTHEWS, 1994; MACHADO, 1995 e 2000). Assim, não é de meu interesse descrever os diálogos que ocorreram na mediação do professor e na interação aluno-aluno e aluno-professor. A postura mediadora do professor foi voltada para a discussão dos resultados obtidos nos experimentos e através da comparação dos resultados entre os grupos, além de discutir possíveis erros ou discrepâncias nos resultados de um grupo ou de outro. Nesta etapa, todos os alunos participaram da atividade experimental, que foi feita em grupos de quatro a cinco alunos. Esses grupos foram selecionados por mim, de forma a deixar os alunos que já haviam conseguido responder às questões operatórias na Etapa 2 participando de grupos com alunos que não haviam conseguido resolvê-las, para estimular tais alunos a ensinarem seus colegas com maiores dificuldades. Após a execução da parte experimental foi feita a discussão e, posteriormente, os alunos tiveram que, individualmente, responder por escrito a algumas perguntas referentes e/ou relacionadas ao experimento (perguntas localizadas no final dos roteiros em anexo). 
Etapa 4 - reaplicação de cinco exercícios considerados como operatórios (exercícios que envolvam o mesmo conceito, mas que não sejam idênticos ao que foi aplicado na Etapa 2). A intenção era verificar se houve uma evolução no nível cognitivo após a intervenção com a atividade experimental.

Etapa 5 - aplicação de cinco exercícios operatórios após três meses da realização da Etapa 4. Esses exercícios foram os mesmos aplicados de acordo com a Etapa 2; cabe ressaltar que essa aplicação foi feita sem prévio aviso para verificar realmente se, após um certo tempo, o aprendizado permaneceu ou se os conceitos foram esquecidos.

É importante mencionar que os exercícios operatórios foram especialmente formulados por mim ou aproveitados de livros didáticos, de vestibulares etc. Além disso, a classificação dos exercícios abordados neste trabalho em operatórios ou nãooperatórios foi validada pela apreciação de três professores de Química de Ensino Médio de competência reconhecida. Isso respalda que a classificação que havia proferido está de acordo com a opinião de outros professores. É claro que há uma margem de subjetividade, mas nada que chegasse ao extremo.

Um dos principais objetivos desta pesquisa é estudar os alunos que possuem dificuldades em conceitos químicos através da reconstrução da prática avaliativa. A aplicação de exercícios operatórios pré e pós-reconstrução da prática avaliativa é uma ótima ferramenta para diagnosticar dificuldades (e habilidades) e essa terapia será oferecida principalmente visando os alunos com dificuldades.

Após uma discussão contextualizada em sala de aula, os alunos responderam individualmente e sem consulta a cinco exercícios ditos não-operatórios (Etapa 1) e a 
cinco exercícios ditos operatórios (Etapa 2). Neste trabalho serão dados exemplos de um exercício operatório e um não-operatório de cada tema / ano. O material completo está em anexo neste trabalho. Esses exercícios foram aplicados em uma data agendada por mim com o propósito do aluno estudar e, posteriormente, tentar investigar como ele estuda. Após a intervenção com a atividade experimental (Etapa 3), foram aplicados mais cinco exercícios de caráter operatório (Etapa 4) e, após passados três meses da Etapa 4, foram aplicados novamente os exercícios operatórios da Etapa 2, correspondendo à Etapa 5.

Para isso, irei transcrever as respostas de alguns alunos exatamente como eles escreveram (seja lá com erros de ortografia, concordância, etc ou sem estes deslizes).

Com o propósito de preservar a identidade dos alunos, irei transcrever as respostas de alguns deles através do seguinte código: $\mathrm{X}-\mathrm{Y}$, onde " $\mathrm{X}$ " corresponde à série do aluno ( $1^{\circ}$ ou $2^{\circ}$ ano do Ensino Médio) e "Y" ao número de chamada desse aluno. Assim, um aluno do $1^{\circ}$ ano cujo número de chamada é 5 será chamado de 1-5; um aluno do $2^{\circ}$ ano cujo número de chamada é 10 será chamado de 2-10 e assim por diante. 


\section{CAPÍTULO 4: RESULTADOS E DISCUSSÃO}

\section{1 - Conteúdo: Separação de Misturas (alunos do 1ano)}

Esse conteúdo foi selecionado por se tratar de um assunto que está presente no cotidiano do aluno. Além disso, percebi durante minha vivência como professor que muitos alunos dão uma maior prioridade a memorizar os nomes das técnicas de separação do que para a argumentação de como se separar. O número de alunos do $1^{\circ}$ ano desse colégio foi 35 .

Os processos utilizados para a extração de substâncias, chamados de separação de misturas ou purificação de materiais, correspondem a uma das atividades básicas do químico. Muitos desses processos são utilizados diariamente pelos alunos ou, pelo menos, estão presentes no seu dia-a-dia. Entre esses processos, podemos citar: coar o café, catar o feijão, centrifugar a roupa na máquina de lavar, aspirar a poeira do chão, fazer coleta seletiva de lixo, etc.

\subsection{1 - Aplicação de exercícios não-operatórios e operatórios}

\section{Exercício não-operatório 1:}

(U. F. Santa Maria - RS) Num acampamento, todo o sal de cozinha foi derramado na areia. As pessoas recuperaram o sal realizando, sucessivamente, as operações de:

a) dissolução, filtração, evaporação.

b) fusão, decantação e sublimação. 
c) liquefação, filtração e vaporização.

d) adição de água e destilação.

e) diluição, sedimentação e vaporização.

Resposta correta: alternativa "a"

Resultado: dos 35 alunos, 30 (94,3\%) acertaram esse exercício.

Comentário: esse exercício é tipicamente de caráter não-operatório, pois exige que o aluno saiba apenas os nomes dos processos exigindo, a certo ponto, uma memorização que, provavelmente ocorreu pelo fato desse exemplo estar bastante presente nos livros didáticos (no caso desses alunos, um material apostilado). Dois dos alunos (1-33 e 1-34) que não acertaram deixaram toda a parte dissertativa em branco, o que pressupõe que não houve qualquer tipo de estudo.

\section{Exercício operatório 1:}

(UNICAMP) Em um acampamento, um estudante deixou cair na areia todo o sal de cozinha disponível. Entretanto, tendo conhecimento sobre separação de misturas, conseguiu recuperar todo o sal. Que operações este estudante pode ter realizado? Explique.

Resultado: dos 35 alunos, 18 (51,4\%) acertaram esse exercício. Dos 17 alunos que não acertaram o exercício, dois (1-33 e 1-34) deixaram em branco, 10 cometeram erros conceituais por completo e cinco acertaram parcialmente a resposta. 


\section{Algumas respostas consideradas corretas:}

- Resposta do 1-4: "Primeiro o estudante coloca água na mistura de sal e areia. Após o sal irá dissolver na água e a areia irá para o fundo do recipiente. Depois, separa a água com sal dissolvido da areia por um coador e depois o estudante aquece a água com sal, evaporando a água e ficando o sal na panela, processo finalizado".

- Resposta do 1-7: "Este estudante poderia ter realizado a dissolução fracionada, a filtração e a evaporação. Pegaria a mistura areia + sal e colocaria água, dissolvendo o sal. Filtraria a mistura, retirando a areia. Aqueceria a água + sal dissolvido, assim a água evaporaria, obtendo-se o sal".

- Resposta do 1-11: "Ele usou a dissolução fracionada e o sal se dissolveu na água. Depois usou a filtração para separar a água com sal dissolvido da areia. Depois ele evaporou a água com sal e restou apenas o sal no fundo".

- Resposta do 1-20:

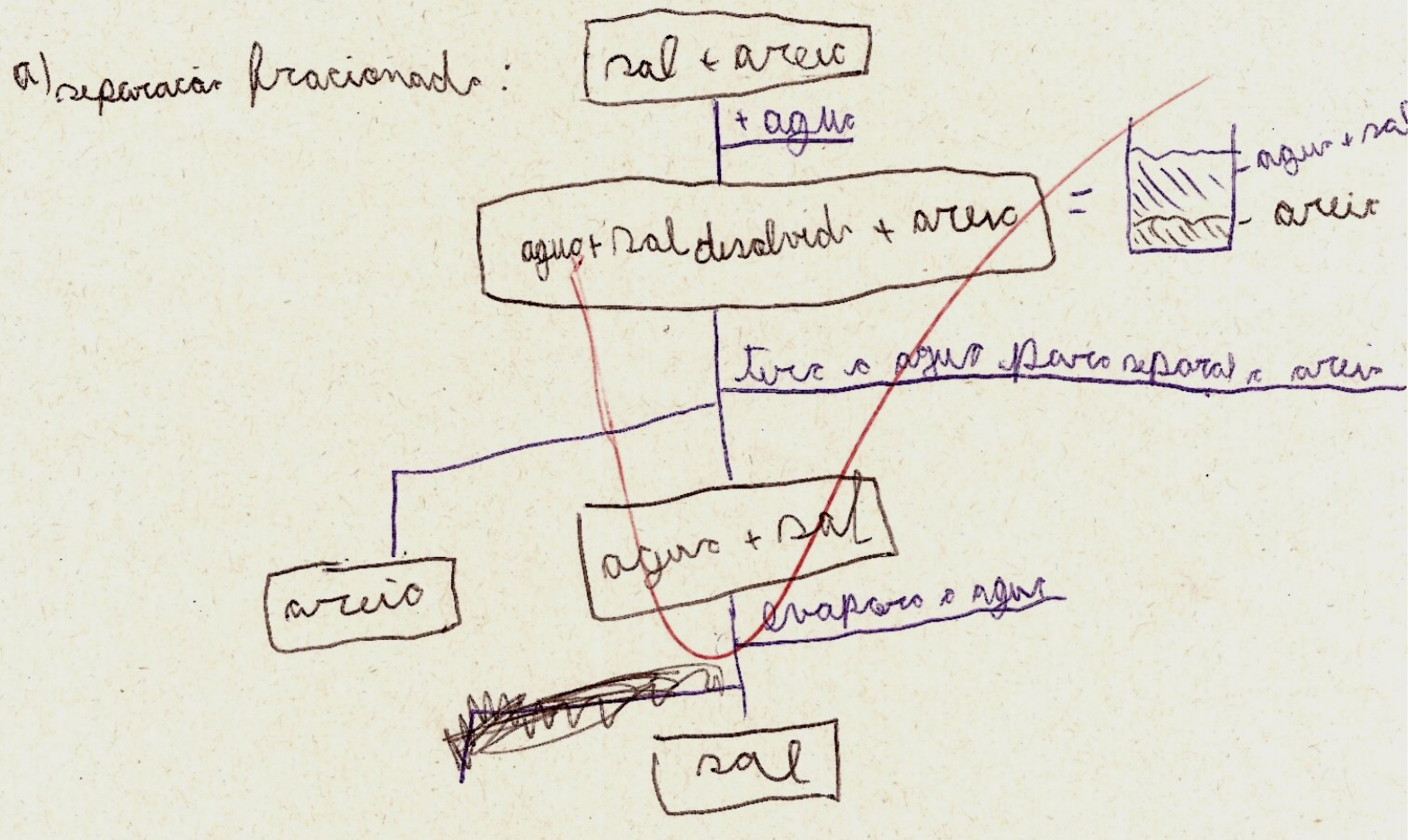




\section{Algumas respostas consideradas parcialmente corretas:}

- Resposta do aluno 1-12: "Ele pode ter usado a filtração, pois tinha que juntar água, filtrar e assim ficaria apenas a água com sal e depois usou a evaporação".

- Resposta do aluno 1-25: "Primeiro ele pos água o sal se disolveu tirou a água e a areia ficou no recipiente. Então evaporou a água sobrando apenas o sal”.

\section{Algumas respostas consideradas incorretas:}

- Resposta do aluno 1-6: "Colocando água na mistura e depois fazendo destilação, ambos estarão separados".

- Resposta do aluno 1-8: "Dissolução fracionária, pois o sal e a areia não se misturam e a areia não se mistura com o sal".

- Resposta do aluno 1-15: "Jogar água no recipiente com areia e sal, misturar as três substâncias, depois irei utilizar o método da decantação (torneirinha), deixarei a água com o sal passar e a areia ficará no fundo do recipiente. A água e o sal irei usar o processo de solidificação, o sal ficará sólido e a areia ficará em outro recipiente sozinho".

- Resposta do aluno 1-30: "O estudante pode ter colocado tudo num recipiente com água e esquentada a água, a água iria evaporar e o sal ficaria, depois ele separaria o sal da areia com a mão".

Comentário: esse exercício é de caráter operatório, pois exige que o aluno deixe de lado a memorização e comece a estabelecer relações com base em fatos, ideias, etc. Não basta o aluno saber o nome dos processos. É preciso raciocinar e descrever um 
método coerente para separação. Nota-se que um percentual bem menor de alunos acertou por completo esta questão, sendo que, a princípio, o conteúdo dessa pergunta é semelhante ao do exercício não-operatório 1. É interessante mencionar de que três alunos (como, por exemplo, o aluno 1-4) que erraram o exercício não-operatório 1 , acertaram o exercício operatório 1. Isso pode ser explicado pelo fato destes alunos terem dado prioridade à compreensão dos conceitos e não à memorização dos nomes dos processos.

Além disso, a resposta do aluno 1-20 foi bastante interessante: ele resolveu o exercício através de um fluxograma. Este aluno, segundo um princípio de reversibilidade (PIAGET e INHELDER, 1966) encontrou uma alternativa de solução. Como professores, temos que ter uma ação avaliativa que abranja a compreensão do processo de cognição. As respostas dos alunos 1-12 e 1-25, consideradas como parcialmente corretas, mostram que o aluno deixou de explicitar alguns processos intermediários para a separação da mistura em questão. Isso pode ter sido ocasionado pelo fato deles terem tentado memorizar o processo e, no momento da arguição, esqueceram algumas etapas. Assim, esses tipos de respostas podem ser considerados como não aprendidos pelos alunos. Já os alunos 1-6, 1-8, 1-15 e 1-30 erraram o exercício, pois demonstraram possuir alguns erros conceituais. Os alunos 1-6 e 1-30 mostram que sabem que é necessário adicionar água à mistura, mas não sabem o motivo. Já o aluno 1-15 cometeu um erro conceitual sobre densidade, além de ter confundido a evaporação com a solidificação. 


\subsection{2 - A atividade experimental de caráter investigativo (reconstrução da prática avaliativa)}

A atividade experimental (roteiro nos Anexos) foi executada com três grupos de cinco alunos e cinco grupos com quatro alunos. Cada grupo recebeu uma mistura composta por cloreto de sódio ( $\mathrm{NaCl}$, principal componente do sal de cozinha), carbonato de cálcio $\left(\mathrm{CaCO}_{3}\right.$, principal componente do mármore), grãos de feijão, areia, grampos de grampeador. Os alunos tiveram que separar os componentes dessa mistura apenas com os materiais e reagentes fornecidos nas bancadas.

No roteiro experimental foram dadas três dicas: 1) cloreto de sódio é solúvel em água; 2) carbonato de cálcio é insolúvel em água; 3) no caso desse experimento, o carbonato de cálcio poderia ser descartado.

Os alunos, através da organização de suas ideias, tiveram que formular hipóteses, executar a parte experimental para que o objetivo fosse alcançado. Como mediador, fui apenas orientando os alunos a organizarem tais ideias, sugerindo alguns métodos através de outras dicas.

Uma das maneiras (a mais convencional) de alcançar tal objetivo seria: 1) retirar os grãos de feijão com as mãos; 2) retirar os grampos de grampeador com um ímã; 3) adicionar água - nesse caso, o cloreto de sódio seria dissolvido pela água e o carbonato de cálcio e a areia, não; 4) filtrar - nesse caso, passaria pelo papel de filtro o cloreto de sódio dissolvido em água e ficariam retidos no papel de filtro, a areia e o carbonato de cálcio; 5) adicionar ácido clorídrico diluído sobre a mistura de areia e carbonato de cálcio - nesse caso, o carbonato de cálcio irá reagir com o ácido clorídrico diluído e ficará retido no papel apenas a areia. 
É importante salientar que essa sequência não foi seguida por todos os grupos. Por exemplo, alguns grupos adicionaram água logo no início do experimento; no final, tais grupos conseguiram alcançar o objetivo. Isso mostra que o experimento é de caráter investigativo, pois os próprios alunos propuseram uma metodologia para que o objetivo fosse alcançado, ou seja, houve ação e reflexão.

Como os próprios alunos deveriam propor os métodos para separação da mistura em questão, percebi que houve uma participação muito grande por parte de todos os alunos.

\subsection{3 - Aplicação de exercícios operatórios após a reconstrução da prática avaliativa}

Uma boa parte dos alunos que respondiam os exercícios operatórios na Etapa 2 sem estabelecerem relações entre fatos, fenômenos, idéias, passaram a respondê-los através de ações mais elaboradas e complexas.

Os resultados indicados no Quadro II abaixo mostram um efeito comparativo dos alunos antes e após a reconstrução da prática avaliativa. 
Quadro II - Resultados obtidos pelos alunos do $1^{\circ}$ ano antes e após a reconstrução da prática avaliativa

\begin{tabular}{|c|c|c|c|c|}
\hline \multirow{2}{*}{ Aluno } & \multicolumn{2}{|c|}{ Resultados antes da reconstrução da prática avaliativa } & \multirow{2}{*}{$\begin{array}{c}\text { Resultados após a reconstrução } \\
\text { da prática avaliativa } \\
\mathrm{N}^{\circ} \text { de acertos nas questões } \\
\text { operatórias }\end{array}$} & \multirow{2}{*}{ Evolução* } \\
\hline & $\begin{array}{c}\mathrm{N}^{\circ} \text { de acertos nas questões } \\
\text { não-operatórias }\end{array}$ & $\begin{array}{c}\mathrm{N}^{\circ} \text { de acertos nas questões } \\
\text { operatórias }\end{array}$ & & \\
\hline $1-1$ & 4 & 2,5 & 3,5 & +1 \\
\hline $1-2$ & 4 & 2,5 & 4 & $+1,5$ \\
\hline $1-3$ & 3 & 2 & 4 & +2 \\
\hline $1-4$ & 3 & 3 & 3 & 0 \\
\hline $1-5$ & 3,5 & 2,5 & 3 & $+0,5$ \\
\hline $1-6$ & 2 & 1 & 2,5 & $+1,5$ \\
\hline $1-7$ & 5 & 5 & 5 & 0 \\
\hline $1-8$ & 3 & 3 & 3,5 & $+0,5$ \\
\hline $1-9$ & 4 & 2,5 & 3,5 & +1 \\
\hline $1-10$ & 4,5 & 2 & 3,5 & $+1,5$ \\
\hline $1-11$ & 5 & 3 & 5 & +2 \\
\hline $1-12$ & 4 & 2 & 4 & +2 \\
\hline $1-13$ & 5 & 4 & 4,5 & $+0,5$ \\
\hline $1-14$ & 5 & 4 & 4 & 0 \\
\hline $1-15$ & 2 & 2 & 3 & +1 \\
\hline $1-16$ & 4,5 & 3 & 3,5 & $+0,5$ \\
\hline $1-17$ & 4 & 3 & 3,5 & $+0,5$ \\
\hline $1-18$ & 3,5 & 3 & 3,5 & $+0,5$ \\
\hline $1-19$ & 4,5 & 3 & 3,5 & $+0,5$ \\
\hline $1-20$ & 5 & 5 & 5 & 0 \\
\hline $1-21$ & 5 & 2,5 & 4,5 & +2 \\
\hline $1-22$ & 4 & 2 & 4 & +2 \\
\hline $1-23$ & 3 & 3 & 4 & +1 \\
\hline $1-24$ & 3,5 & 2,5 & 4 & $+1,5$ \\
\hline $1-25$ & 4 & 2,5 & 3 & $+0,5$ \\
\hline $1-26$ & 4,5 & 3,5 & 3 & $-0,5$ \\
\hline $1-27$ & 5 & 3,5 & 5 & $+1,5$ \\
\hline $1-28$ & 5 & 4 & 3,5 & $-0,5$ \\
\hline $1-29$ & 4 & 2,5 & 3,5 & +1 \\
\hline $1-30$ & 3 & 2,5 & 3 & $+0,5$ \\
\hline $1-31$ & 2 & 1 & 2 & +1 \\
\hline $1-32$ & 3 & 1 & 2,5 & $+1,5$ \\
\hline $1-33$ & 1 & 0 & 2 & +2 \\
\hline $1-34$ & 1 & 0 & 2,5 & $+2,5$ \\
\hline $1-35$ & 4 & 2 & 3,5 & $+1,5$ \\
\hline Média & 3,7 & 2,6 & 3,6 & $+1,0$ \\
\hline
\end{tabular}

* A Evolução corresponde à diferença do número de acertos dos exercícios operatórios antes e após a reconstrução da prática avaliativa (intervenção através do experimento investigativo). 
Estes mesmos resultados podem ser também visualizados nos Gráficos I e II.

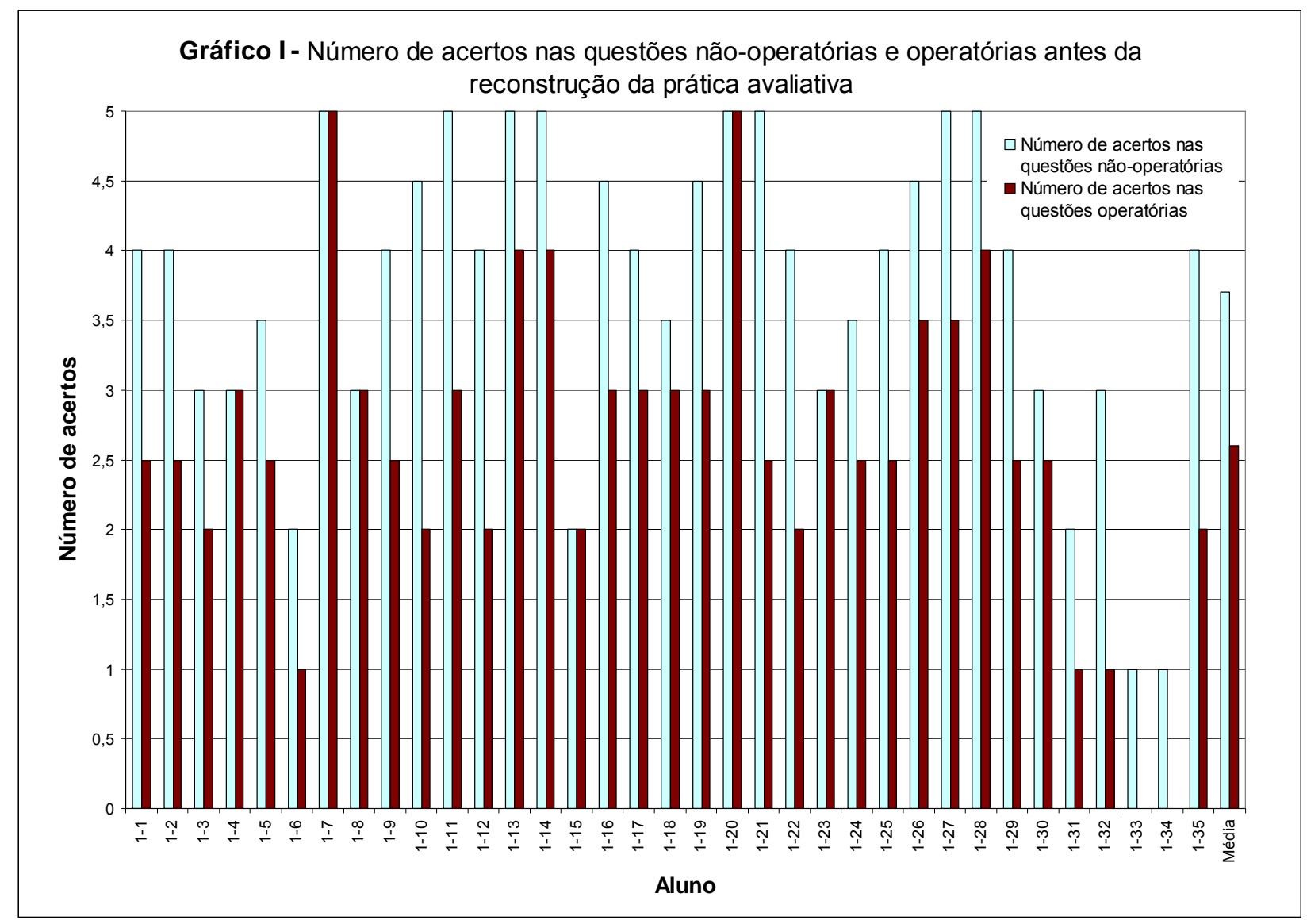

Analisando o Quadro II e o Gráfico I, verifica-se que 29 (82,9\%) dos 35 alunos apresentaram maiores pontuações nas questões não-operatórias em relação às operatórias. Esse dado pode ser explicado levando-se em consideração que os alunos resolveram os exercícios, em sua grande maioria, através da utilização de um algoritmo ou de uma memorização. Verifica-se também que apenas dois alunos (1-7 e 1-20) acertaram todas as questões (não-operatórias e operatórias).

A reconstrução da prática avaliativa consistiu em um experimento de caráter investigativo com uma posterior discussão do mesmo, levando-se em conta sempre os resultados obtidos pelos alunos. 


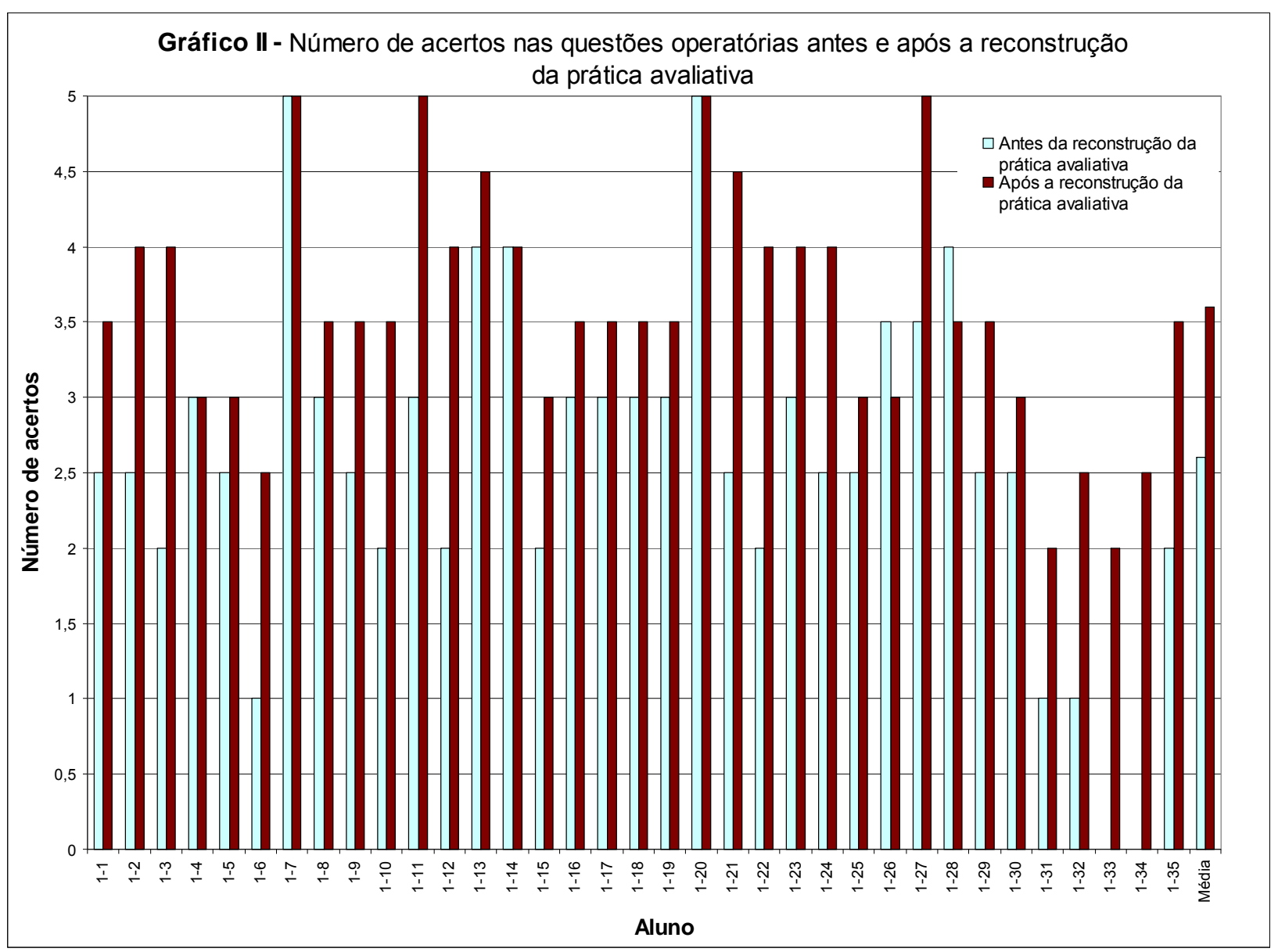

O Quadro I e o Gráfico II indicam uma evolução significativa de boa parte dos alunos após a intervenção com o experimento investigativo. Nota-se que 30 (85,7\%) dos 35 alunos apresentaram melhora quando comparamos o número de acertos pré e pós-reconstrução da prática avaliativa (considerando apenas as questões que exigem maiores habilidades e que dificilmente possam ser resolvidos por algoritmo ou memorização, ou seja, os exercícios operatórios). Dos cinco alunos que não apresentaram melhora, dois deles (1-7 e 1-20) acertaram todos os exercícios operatórios (antes e após a reconstrução da prática avaliativa).

Considerando que o nível satisfatório seja de $80 \%$ (4 exercícios operatórios corretos após a reconstrução da prática avaliativa), 12 alunos $(34,3 \%)$ obtiveram tal 
marca. Antes da reconstrução da prática avaliativa, apenas cinco alunos (14,3\%) haviam obtido esse nível de satisfação.

Além disso, se o nível satisfatório considerado for de 60\% (3 exercícios operatórios corretos após a reconstrução da prática avaliativa), 31 alunos (88,6\%) obtiveram tal marca. Antes da reconstrução da prática avaliativa, apenas 15 alunos (42,9\%) haviam obtido esse nível de satisfação.

Quando se compara a média da sala, também verifica-se uma notável melhora. O número de acertos médio dos exercícios operatórios antes do experimento foi de 2,6 e após a discussão do experimento, 3,6. Ou seja, houve uma melhora considerável correspondente à diferença de uma questão.

\subsection{4 - Aplicação de novos exercícios operatórios na Etapa 5}

Visando verificar se, após um certo tempo, o aprendizado permaneceu ou se os conceitos foram esquecidos, foi feita uma nova aplicação de exercícios operatórios sobre o tema "Separação de Misturas". O resultado comparativo entre a aplicação de exercícios operatórios nas Etapas 4 e 5 (após três meses da Etapa 4) é mostrado no Quadro III a seguir. 
Quadro III - Resultados obtidos pelos alunos do $1^{\circ}$ ano após a reconstrução da prática avaliativa (Etapa 4) e após 3 meses dessa etapa (Etapa 5)

\begin{tabular}{|c|c|c|c|}
\hline \multirow{2}{*}{ Aluno } & \multicolumn{2}{|c|}{ Número de acertos nas questões operatórias } & \multirow{2}{*}{ Evolução* } \\
\hline & Etapa 4 & Etapa 5 & \\
\hline $1-1$ & 3,5 & 3 & $-0,5$ \\
\hline $1-2$ & 4 & 3,5 & $-0,5$ \\
\hline $1-3$ & 4 & 4,5 & $+0,5$ \\
\hline $1-4$ & 3 & 3 & 0 \\
\hline $1-5$ & 3 & 3 & 0 \\
\hline $1-6$ & 2,5 & 3 & $+0,5$ \\
\hline $1-7$ & 5 & 5 & 0 \\
\hline $1-8$ & 3,5 & 3 & $-0,5$ \\
\hline $1-9$ & 3,5 & 3,5 & 0 \\
\hline $1-10$ & 3,5 & 3,5 & 0 \\
\hline $1-11$ & 5 & 4 & -1 \\
\hline $1-12$ & 4 & 4 & 0 \\
\hline $1-13$ & 4,5 & 5 & $+0,5$ \\
\hline $1-14$ & 4 & 4,5 & $+0,5$ \\
\hline $1-15$ & 3 & 3,5 & $+0,5$ \\
\hline $1-16$ & 3,5 & 3,5 & 0 \\
\hline $1-17$ & 3,5 & 3 & $-0,5$ \\
\hline $1-18$ & 3,5 & 2,5 & -1 \\
\hline $1-19$ & 3,5 & 3 & $-0,5$ \\
\hline $1-20$ & 5 & 5 & 0 \\
\hline $1-21$ & 4,5 & 4 & $-0,5$ \\
\hline $1-22$ & 4 & 4 & 0 \\
\hline $1-23$ & 4 & 4,5 & $+0,5$ \\
\hline $1-24$ & 4 & 3,5 & $-0,5$ \\
\hline $1-25$ & 3 & 3,5 & $+0,5$ \\
\hline $1-26$ & 3 & 3,5 & $+0,5$ \\
\hline $1-27$ & 5 & 4 & -1 \\
\hline $1-28$ & 3,5 & 4,5 & +1 \\
\hline $1-29$ & 3,5 & 4 & $+0,5$ \\
\hline $1-30$ & 3 & 3,5 & $+0,5$ \\
\hline $1-31$ & 2 & 2,5 & $+0,5$ \\
\hline $1-32$ & 2,5 & 2,5 & 0 \\
\hline $1-33$ & 2 & 2,5 & $+0,5$ \\
\hline $1-34$ & 2,5 & 3 & $+0,5$ \\
\hline $1-35$ & 3,5 & 3 & $-0,5$ \\
\hline Média & 3,6 & 3,6 & 0 \\
\hline
\end{tabular}

* A Evolução corresponde à diferença do número de acertos dos exercícios operatórios entre as Etapas 4 e 5 . 
Estes resultados também podem ser visualizados no Gráfico III a seguir.

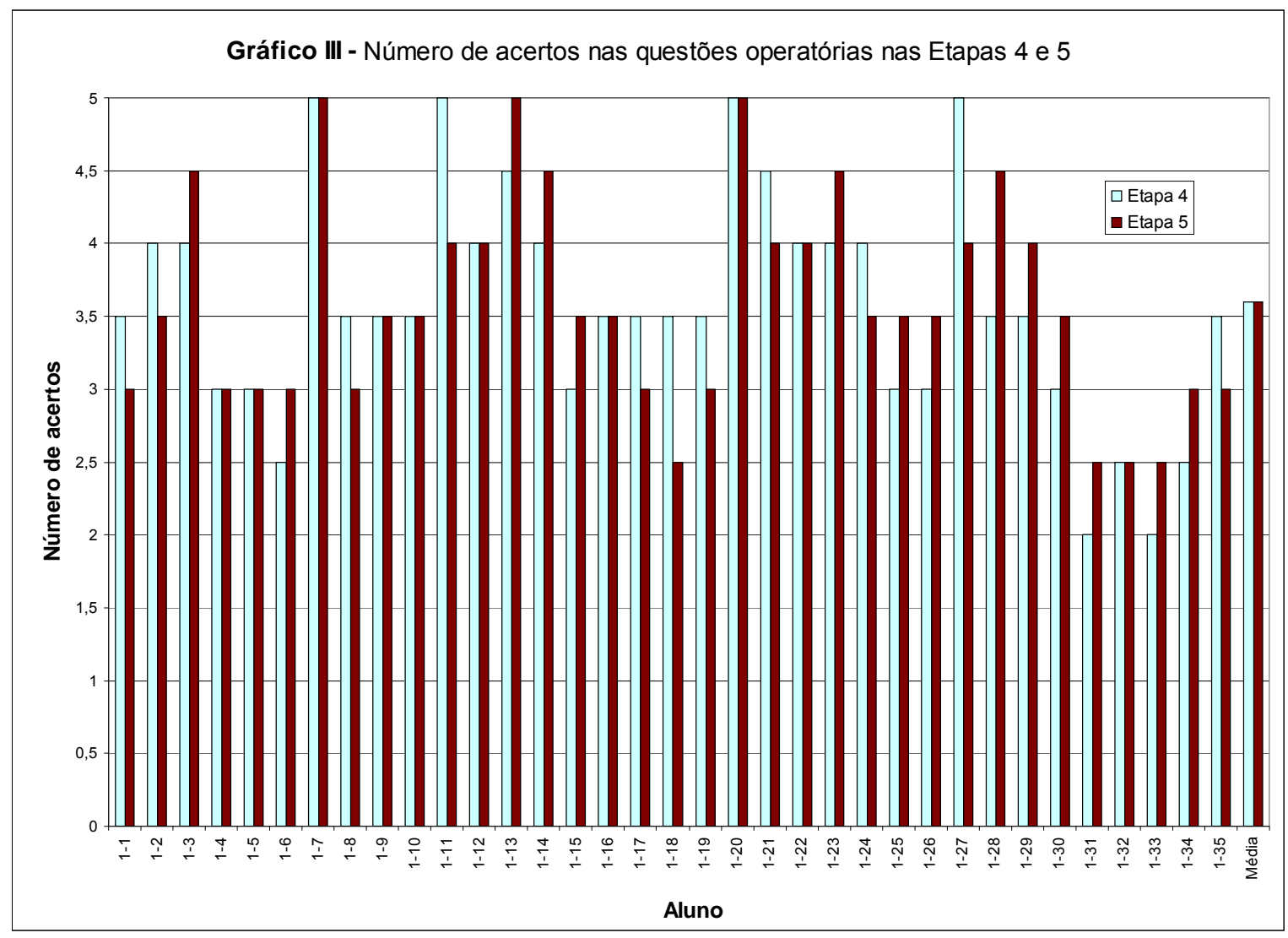

Alguns dados interessantes podem ser verificados no Quadro III e no Gráfico III. Mesmo após três meses da última aplicação de exercícios operatórios, a média de acertos se manteve: 3,6. Isso sugere que, em termos gerais, os alunos obtiveram um aumento da aprendizagem significativa. Analisando de maneira individualizada, verificase que apenas 11 alunos $(31,4 \%)$ caíram de rendimento e, mesmo assim, de uma forma relativamente aceitável, visto que a queda foi em torno de 0,5 ponto (meia questão).

Considerando que os exercícios operatórios aplicados na Etapa 2 (antes da intervenção com o experimento investigativo) são os mesmos da Etapa 5, observa-se uma notável melhora no aprendizado dos alunos, conforme representados pelo Quadro IV e Gráfico IV. 
Quadro IV - Resultados obtidos pelos alunos do $1^{\circ}$ ano nas Etapas 2 e 5

\begin{tabular}{|c|c|c|c|}
\hline \multirow{2}{*}{ Aluno } & \multicolumn{2}{|c|}{ Número de acertos nas questões operatórias } & \multirow{2}{*}{ Evolução* } \\
\hline & Etapa 2 & Etapa 5 & \\
\hline $1-1$ & 2,5 & 3 & $+0,5$ \\
\hline $1-2$ & 2,5 & 3,5 & +1 \\
\hline $1-3$ & 2 & 4,5 & $+2,5$ \\
\hline $1-4$ & 3 & 3 & 0 \\
\hline $1-5$ & 2,5 & 3 & $+0,5$ \\
\hline $1-6$ & 1 & 3 & +2 \\
\hline $1-7$ & 5 & 5 & 0 \\
\hline $1-8$ & 3 & 3 & 0 \\
\hline $1-9$ & 2,5 & 3,5 & +1 \\
\hline $1-10$ & 2 & 3,5 & $+1,5$ \\
\hline $1-11$ & 3 & 4 & +1 \\
\hline $1-12$ & 2 & 4 & +2 \\
\hline $1-13$ & 4 & 5 & +1 \\
\hline $1-14$ & 4 & 4,5 & $+0,5$ \\
\hline $1-15$ & 2 & 3,5 & $+1,5$ \\
\hline $1-16$ & 3 & 3,5 & $+0,5$ \\
\hline $1-17$ & 3 & 3 & 0 \\
\hline $1-18$ & 3 & 2,5 & $-0,5$ \\
\hline $1-19$ & 3 & 3 & 0 \\
\hline $1-20$ & 5 & 5 & 0 \\
\hline $1-21$ & 2,5 & 4 & $+1,5$ \\
\hline $1-22$ & 2 & 4 & +2 \\
\hline $1-23$ & 3 & 4,5 & $+1,5$ \\
\hline $1-24$ & 2,5 & 3,5 & +1 \\
\hline $1-25$ & 2,5 & 3,5 & +1 \\
\hline $1-26$ & 3,5 & 3,5 & 0 \\
\hline $1-27$ & 3,5 & 4 & $+0,5$ \\
\hline $1-28$ & 4 & 4,5 & $+0,5$ \\
\hline $1-29$ & 2,5 & 4 & $+1,5$ \\
\hline $1-30$ & 2,5 & 3,5 & +1 \\
\hline $1-31$ & 1 & 2,5 & $+1,5$ \\
\hline $1-32$ & 1 & 2,5 & $+1,5$ \\
\hline $1-33$ & 0 & 2,5 & $+2,5$ \\
\hline $1-34$ & 0 & 3 & +3 \\
\hline $1-35$ & 2 & 3 & +1 \\
\hline Média & 2,6 & 3,6 & +1 \\
\hline
\end{tabular}

* A Evolução corresponde à diferença do número de acertos dos exercícios operatórios entre as Etapas 2 e 5 


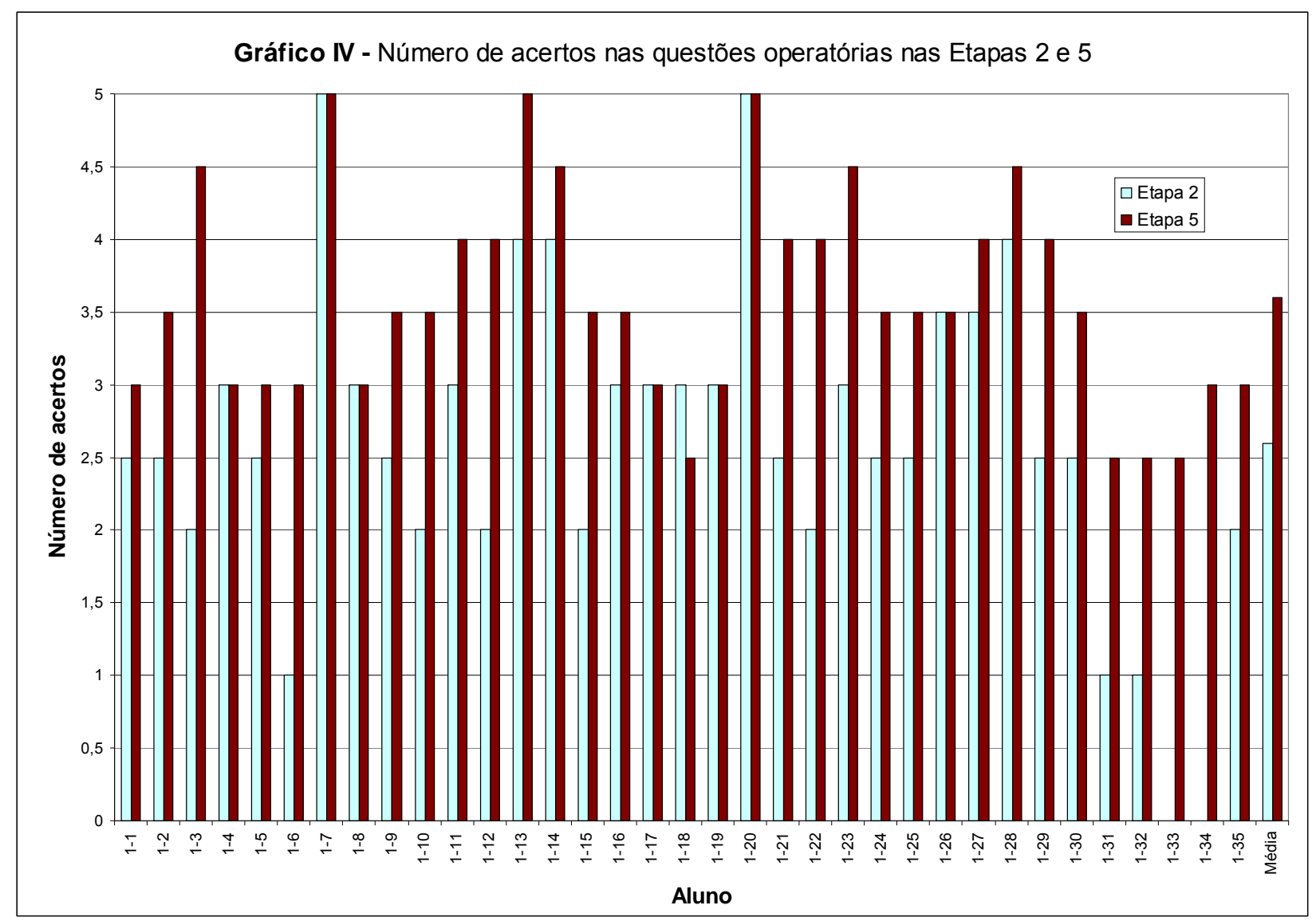

Analisando o Gráfico IV, verifica-se que dos 35 alunos, 27 (77\%) apresentaram uma evolução com relação à resolução das questões operatórias e apenas um aluno $(2,9 \%)$, aluno $1-18$, caiu de rendimento. Isso indica que houve um aumento na aprendizagem significativa por parte dos alunos. 


\section{2 - Conteúdo: Cinética Química (alunos do 2ำano)}

Esse conteúdo foi selecionado por se tratar de um assunto em que os alunos, mesmo já tendo estudado temas como átomos, reações químicas e ligações químicas, possuem uma grande diversidade de concepções alternativas e uma não-linearidade na concepção da matéria (ANDERSSON, 1990; JUSTI e RUAS, 1997). O número de alunos do $2^{\circ}$ ano desse colégio foi 16 .

\subsection{1 - Aplicação de exercícios não-operatórios e operatórios Exercício não-operatório 1:}

Qual é a influência da superfície de contato na rapidez de uma reação química?

Resultado: dos 16 alunos, 12 (75\%) acertaram esse exercício. A resposta mais comum dada pelos alunos foi a de que quanto maior a superfície de contato entre as partículas dos reagentes, maior será a frequência de choques entre elas, o que provoca um aumento de choques efetivos e influencia no aumento da rapidez da reação.

Comentário: esse exercício é considerado de caráter não-operatório, pois exige que o aluno apenas memorize tal situação. Ou seja, o aluno não necessariamente precisa compreender o que é um choque efetivo, por exemplo. Basta este aluno lembrar do princípio básico da Teoria das Colisões que a probabilidade de acerto é muito grande. 


\section{Exercício operatório 1:}

Juscelino está prestes a viajar para a Europa. Para se despedir dos amigos, organizou uma "churrascada" em sua casa na hora do almoço (12h00). Os amigos iam chegando aos poucos e Juscelino, muito receptivo, falava sobre seus planos para o futuro. Eram $16 \mathrm{~h} 00$ e Juscelino, muito distraído, havia se esquecido completamente do churrasco. Seus amigos começaram a reclamar dizendo que estavam com muita fome e pediram para que Juscelino assasse o churrasco o mais breve possível.

Apesar de distraído, Juscelino é muito esperto: colocou pequenos pedaços de carvão (ao invés de pedaços grandes) e ficou abanando a brasa frequentemente. Assim, o churrasco ficou pronto rapidamente.

Por que colocar pequenos pedaços de carvão faz com que o churrasco asse mais rápido do que com grandes pedaços? Justifique claramente com base na Cinética Química.

Resultado: dos 16 alunos, 5 (31,25\%) acertaram esse exercício. Dos 11 alunos que não acertaram o exercício, nove cometeram erros conceituais por completo e dois acertaram parcialmente a resposta.

\section{Algumas respostas consideradas corretas:}

- Resposta do 2-2: "Quando a superfície de contato é maior, maior será o número de colisões efetivas, ou seja, maior será a rapidez da reação. Ao fazer o seu churrasco, Juscelino resolveu colocar pequenos pedaços de carvão (ao invés de pedaços grandes), aumentando a superfície de contato, assim, aumentando a velocidade da reação". 
- Resposta do 2-11: "Quando o carvão é quebrado em pequenos pedaços, a superfície de contato entre o carvão e o oxigênio do ar aumenta. Assim, haverá um maior número de colisões efetivas entre as moléculas e maior será a rapidez da reação".

\section{Uma resposta considerada parcialmente corretas:}

- Resposta do aluno 2-1:

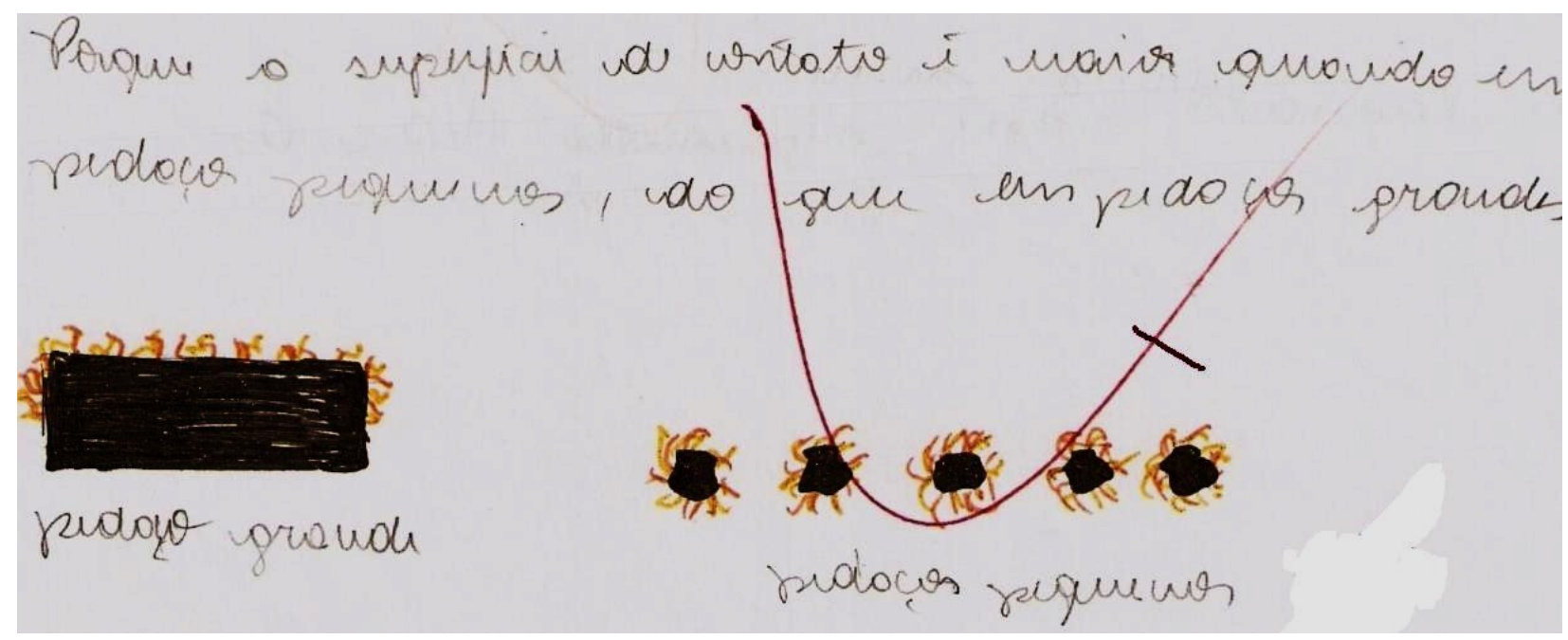

"Porque a superfície de contato é maior quando em pedaços pequenos, do que em pedaços grandes".

\section{Algumas respostas consideradas incorretas:}

- Resposta do aluno 2-5: "O carvão inteiro tem maior superfície de contato por ser maior que o carvão em pedaços. Quando está em pedaços aumenta a superfície de contato, fica mais fácil de queimar".

- Resposta do aluno 2-7: "Quando se faz um churrasco, a temperatura do carvão aumenta, as moléculas vão estar mais agitadas e a velocidade da reação será maior". 
Comentário: esse exercício é de caráter operatório, pois exige que o aluno estabeleça relações com base em fatos, ideias, etc. Não basta o aluno saber responder o exercício não-operatório 1. É preciso raciocinar e saber aplicar tal situação em seu cotidiano. Novamente, verifica-se que um percentual bem menor de alunos acertou por completo esta questão, sendo que, a princípio, o conteúdo dessa pergunta é semelhante ao do exercício não-operatório 1.

A resposta do aluno 2-1 foi considerada parcialmente correta, pois não se sabe se este aluno pensou no Teorema das Colisões. Entretanto, é interessante mencionar que este aluno representou o aumento da superfície de contato a partir de um desenho. Já o aluno 2-5 confundiu o conceito de superfície de contato. Para ele, quanto menor o pedaço, menor é a superfície de contato. Talvez este aluno tenha compreendido o 8Teorema das Colisões, mas demonstrou insegurança com relação ao fator superfície

de contato. Já o aluno 2-7 demonstrou que não interpretou o problema. Isso pode ser decorrência deste aluno ter memorizado algo parecido com a resposta do exercício não-operatório 1 (este aluno acertou o exercício não-operatório 1) e não ter sabido aplicar tal conceito.

\subsection{2 - A atividade experimental de caráter investigativo (reconstrução da prática avaliativa)}

A atividade experimental (roteiro nos Anexos) foi executada com quatro grupos de quatro alunos. Cada grupo recebeu alguns materiais e reagentes e o objetivo era que eles propusessem alguns métodos para verificar como a temperatura, a superfície 
de contato, a concentração e a presença de um catalisador podem influenciar na rapidez de uma transformação química.

Os alunos, através da organização de suas ideias, tiveram que formular hipóteses, executar a parte experimental para que o objetivo fosse alcançado. Como mediador, fui apenas orientando os alunos a organizarem tais ideias, sugerindo alguns métodos através de outras dicas.

Uma das maneiras (a mais convencional) de alcançar tal objetivo seria:

- para verificar a influência da temperatura: pegar dois pedaços iguais do comprimido Sonrisal e adicioná-los ao mesmo tempo, ou ambos triturados ou ambos inteiros, em dois recipientes com a mesma quantidade de água, mas a temperaturas diferentes.

- para verificar a influência da superfície de contato: pegar dois pedaços iguais do comprimido Sonrisal, um triturado e o outro inteiro, e adicioná-los ao mesmo tempo, em dois recipientes com a mesma quantidade de água sob temperaturas iguais.

- para verificar a influência da concentração: pegar a mesma quantidade de raspas de magnésio e adicioná-las, ao mesmo tempo, em dois recipientes com a mesma quantidade de solução de ácido clorídrico com concentrações diferentes (nesse caso, 1 $\mathrm{mol} / \mathrm{L}$ e $2 \mathrm{~mol} / \mathrm{L})$.

- para verificar a influência do catalisador: adicionar uma certa quantidade de água oxigenada sobre um recipiente contendo pedaços de fígado de boi (observação: nesta parte, os alunos receberam a informação do que deveria ser feito).

Como os próprios alunos deveriam propor os métodos para verificar a influência de alguns fatores na rapidez de uma transformação química, percebi que houve uma participação muito grande por parte de todos os alunos. 


\subsection{3 - Aplicação de exercícios operatórios após a reconstrução da prática avaliativa}

Os resultados indicados no Quadro V abaixo mostram um efeito comparativo dos alunos antes e após a reconstrução da prática avaliativa.

Quadro V - Resultados obtidos pelos alunos do $2^{\circ}$ ano antes e após a reconstrução da prática avaliativa

\begin{tabular}{|c|c|c|c|c|}
\hline \multirow{2}{*}{ Aluno } & \multicolumn{2}{|c|}{$\begin{array}{l}\text { Resultados antes da reconstrução da prática } \\
\qquad \text { avaliativa }\end{array}$} & \multirow{2}{*}{$\begin{array}{c}\text { Resultados após a } \\
\text { reconstrução da prática } \\
\text { avaliativa }\end{array}$} & \multirow{2}{*}{ Evolução* } \\
\hline & $\begin{array}{c}\text { No de acertos nas } \\
\text { questões não- } \\
\text { operatórias }\end{array}$ & $\begin{array}{c}\mathrm{N}^{\circ} \text { de acertos nas } \\
\text { questões operatórias }\end{array}$ & & \\
\hline $2-1$ & 4 & 2,5 & 4 & $+1,5$ \\
\hline $2-2$ & 5 & 4 & 5 & +1 \\
\hline $2-3$ & 3 & 2 & 3,5 & $+1,5$ \\
\hline $2-4$ & 3 & 1,5 & 2,5 & +1 \\
\hline $2-5$ & 3 & 1 & 3 & +2 \\
\hline $2-6$ & 3,5 & 2,5 & 3 & $+0,5$ \\
\hline $2-7$ & 4 & 2 & 4 & +2 \\
\hline $2-8$ & 4,5 & 4 & 3 & -1 \\
\hline $2-9$ & 4 & 3 & 4 & +1 \\
\hline $2-10$ & 4 & 1,5 & 3 & $+1,5$ \\
\hline $2-11$ & 4 & 4 & 4 & 0 \\
\hline $2-12$ & 3 & 1 & 2,5 & $+1,5$ \\
\hline $2-13$ & 3,5 & 1,5 & 3 & $+1,5$ \\
\hline $2-14$ & 3 & 2 & 3 & +1 \\
\hline $2-15$ & 3 & 3 & 4,5 & $+1,5$ \\
\hline $2-16$ & 3 & 2 & 4 & +2 \\
\hline Média & 3,6 & 2,3 & 3,5 & $+1,2$ \\
\hline
\end{tabular}

* A Evolução corresponde à diferença do número de acertos dos exercícios operatórios antes e após a reconstrução da prática avaliativa (intervenção através do experimento investigativo). 
Estes mesmos resultados podem ser também visualizados nos Gráficos V e VI.

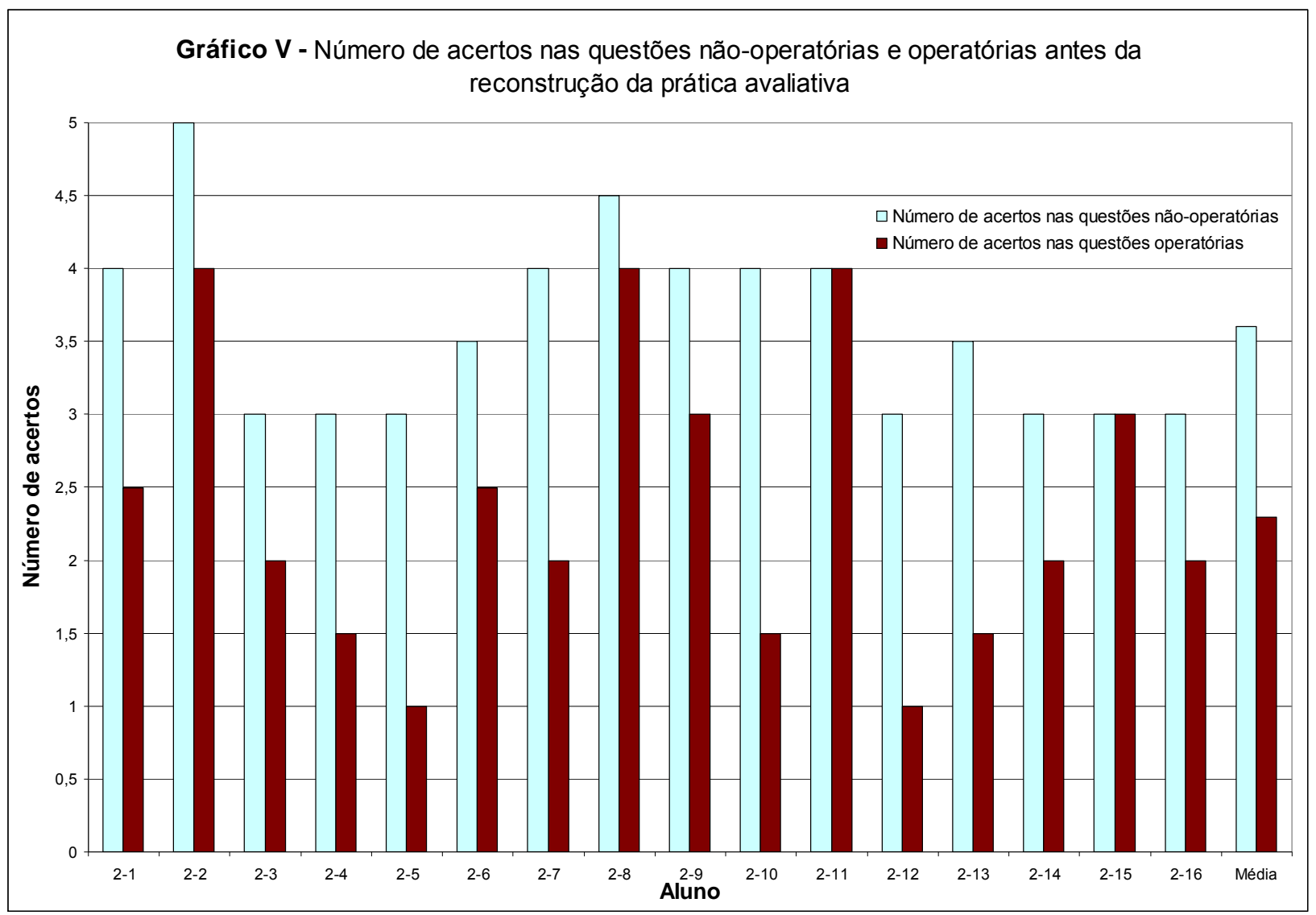

Analisando o Quadro V e o Gráfico V, verifica-se que 14 (87,5\%) dos 16 alunos apresentaram maiores pontuações nas questões não-operatórias em relação às operatórias.

A reconstrução da prática avaliativa consistiu em um experimento de caráter investigativo com uma posterior discussão do mesmo, levando-se em conta sempre os resultados obtidos pelos alunos. O roteiro desse experimento está localizado na parte dos Anexos. 


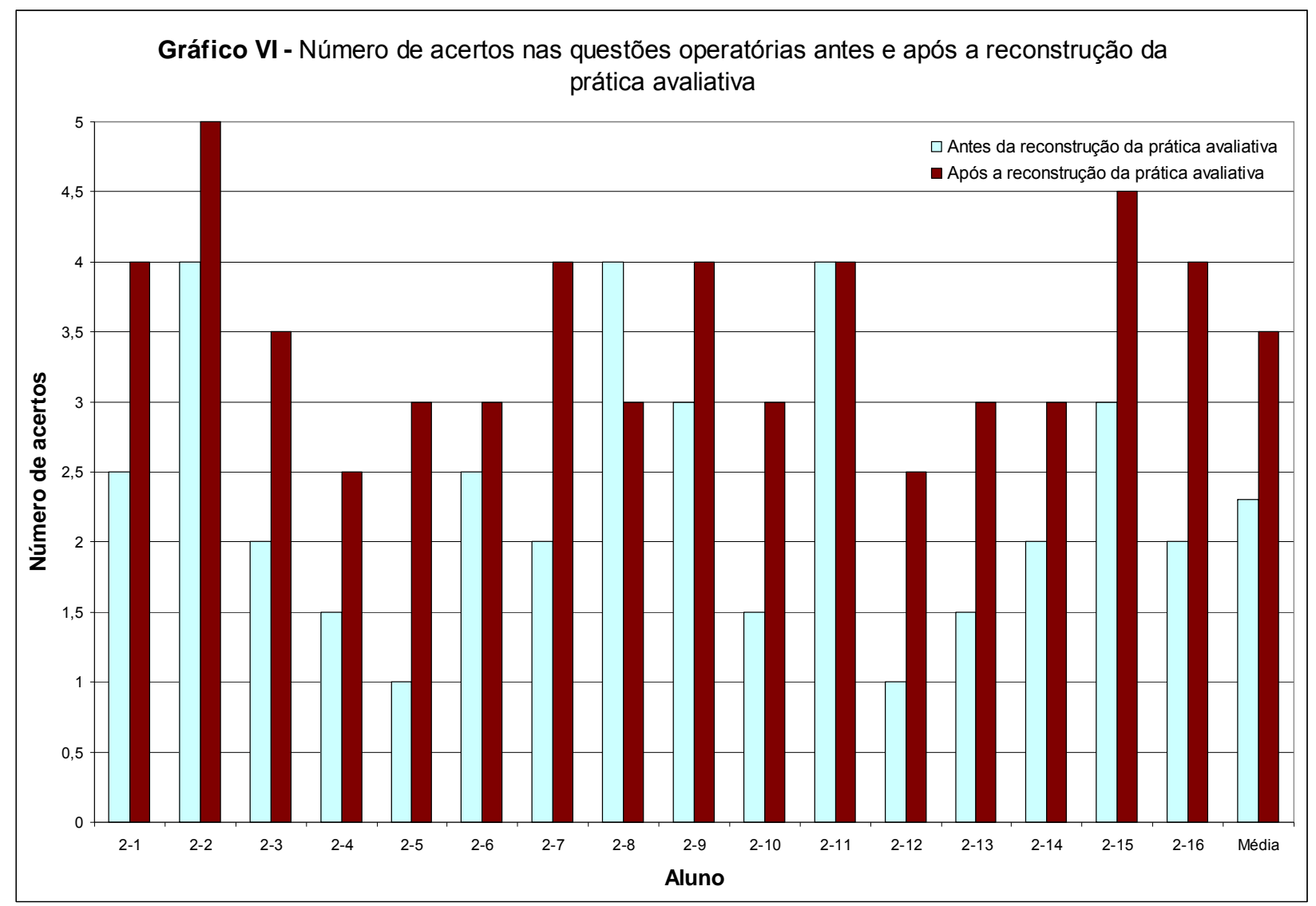

O Quadro V e o Gráfico VI indicam uma evolução significativa de boa parte dos alunos após a intervenção com a atividade experimental. Nota-se que 14 (87,5\%) dos 16 alunos apresentaram melhora quando comparamos o número de acertos pré e pósreconstrução da prática avaliativa (considerando apenas as questões que exigem maiores habilidades e que dificilmente possam ser resolvidos por algoritmo ou memorização, ou seja, os exercícios operatórios).

Considerando que o nível satisfatório seja de $80 \%$ (4 exercícios operatórios corretos após a reconstrução da prática avaliativa), sete alunos $(43,75 \%)$ obtiveram tal marca. Antes da reconstrução da prática avaliativa, apenas três alunos $(18,75 \%)$ haviam obtido esse nível de satisfação. 
Além disso, se o nível satisfatório considerado for de 60\% (3 exercícios operatórios corretos após a reconstrução da prática avaliativa), 14 alunos (87,5\%) obtiveram tal marca. Antes da reconstrução da prática avaliativa, apenas cinco alunos $(31,25 \%)$ haviam obtido esse nível de satisfação.

Quando se compara a média da sala, também verifica-se uma notável melhora. O número de acertos médio dos exercícios operatórios antes do experimento foi de 2,3 e após a discussão do experimento, 3,5.

\subsection{4 - Aplicação de novos exercícios operatórios após três meses do término da última aplicação de exercícios operatórios}

Visando verificar se, após um certo tempo, o aprendizado permaneceu ou se os conceitos foram esquecidos, foi feita uma nova aplicação de exercícios operatórios sobre o tema "Cinética Química". O resultado comparativo entre a aplicação de exercícios operatórios nas Etapas 4 e 5 (após três meses da Etapa 4) é mostrado no Quadro VI a seguir. 
Quadro VI - Resultados obtidos pelos alunos do $2^{\circ}$ ano após a reconstrução da prática avaliativa (Etapa 4) e após 3 meses dessa etapa (Etapa 5)

\begin{tabular}{|c|c|c|c|}
\hline \multirow{2}{*}{ Aluno } & \multicolumn{2}{|c|}{ Número de acertos nas questões operatórias } & \multirow{2}{*}{ Evolução* } \\
\cline { 2 - 3 } & Etapa 4 & Etapa 5 & 0 \\
\hline $2-1$ & 4 & 4 & $-0,5$ \\
\hline $2-2$ & 5 & 4,5 & $+0,5$ \\
\hline $2-3$ & 3,5 & 4 & $+0,5$ \\
\hline $2-4$ & 2,5 & 3 & $-0,5$ \\
\hline $2-5$ & 3 & 2,5 & 0 \\
\hline $2-6$ & 3 & 3 & $-0,5$ \\
\hline $2-7$ & 4 & 3,5 & $-0,5$ \\
\hline $2-8$ & 3 & 2,5 & $-0,5$ \\
\hline $2-9$ & 4 & 3,5 & $+0,5$ \\
\hline $2-10$ & 3 & 3,5 & $-0,5$ \\
\hline $2-11$ & 4 & 3,5 & $+0,5$ \\
\hline $2-12$ & 2,5 & 3 & 0 \\
\hline $2-13$ & 3 & 3 & 0 \\
\hline $2-14$ & 3 & 3 & $-0,5$ \\
\hline $2-15$ & 4,5 & 4 & 0 \\
\hline $2-16$ & 4 & 4 & $-0,1$ \\
\hline Média & 3,5 & 3,4 & 0 \\
\hline
\end{tabular}

* A Evolução corresponde à diferença do número de acertos dos exercícios operatórios entre as Etapas 4 e 5 
Estes resultados também podem ser visualizados no Gráfico VII a seguir.

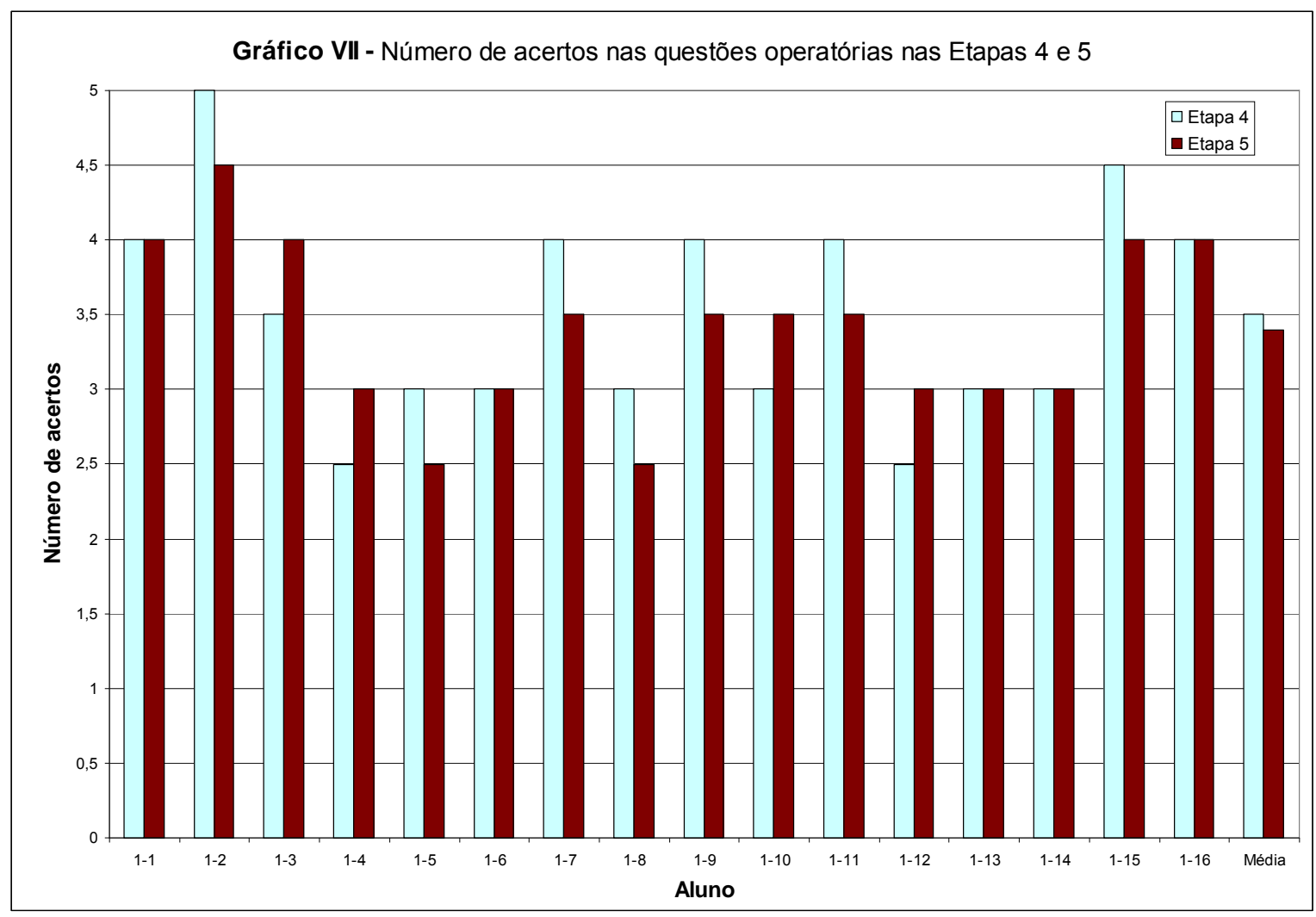

Alguns dados interessantes podem ser verificados no Quadro VI e Gráfico VII. Mesmo após três meses da última aplicação de exercícios operatórios, a média de acertos praticamente se manteve: 3,4 . Isso mostra que, em termos gerais, os alunos obtiveram uma aprendizagem significativa considerável. Analisando de maneira individualizada, verifica-se que apenas sete alunos $(43,75 \%)$ caíram de rendimento e, mesmo assim, de uma forma relativamente aceitável, visto que a queda foi em torno de 0,5 ponto (meia questão).

Considerando que os exercícios operatórios aplicados na Etapa 2 (antes da intervenção com o experimento investigativo) são os mesmos da Etapa 5, observa-se uma notável melhora no aprendizado dos alunos, conforme representados pelo Quadro VII e Gráfico VIII. 
Quadro VII - Resultados obtidos pelos alunos do $2^{\circ}$ ano nas Etapas 2 e 5

\begin{tabular}{|c|c|c|c|}
\hline \multirow{2}{*}{ Aluno } & \multicolumn{2}{|c|}{ Número de acertos nas questões operatórias } & \multirow{2}{*}{ Evolução* } \\
\cline { 2 - 3 } & Etapa 2 & Etapa 5 & $+1,5$ \\
\hline $2-1$ & 2,5 & 4 & $+0,5$ \\
\hline $2-3$ & 4 & 4,5 & +2 \\
\hline $2-4$ & 2 & 4 & $+1,5$ \\
\hline $2-5$ & 1,5 & 3 & $+1,5$ \\
\hline $2-6$ & 1 & 2,5 & $+0,5$ \\
\hline $2-7$ & 2,5 & 3 & $+1,5$ \\
\hline $2-8$ & 2 & 3,5 & $-1,5$ \\
\hline $2-9$ & 4 & 2,5 & $+0,5$ \\
\hline $2-10$ & 3 & 3,5 & +2 \\
\hline $2-11$ & 1,5 & 3,5 & $-0,5$ \\
\hline $2-12$ & 4 & 3,5 & +2 \\
\hline $2-13$ & 1 & 3 & $+1,5$ \\
\hline $2-14$ & 1,5 & 3 & +1 \\
\hline $2-15$ & 2 & 3 & $+1,1$ \\
\hline $2-16$ & 3 & 4 & +1 \\
\hline Média & 2,3 & 3,4 & +1 \\
\hline
\end{tabular}

* A Evolução corresponde à diferença do número de acertos dos exercícios operatórios entre as Etapas 2 e 5 


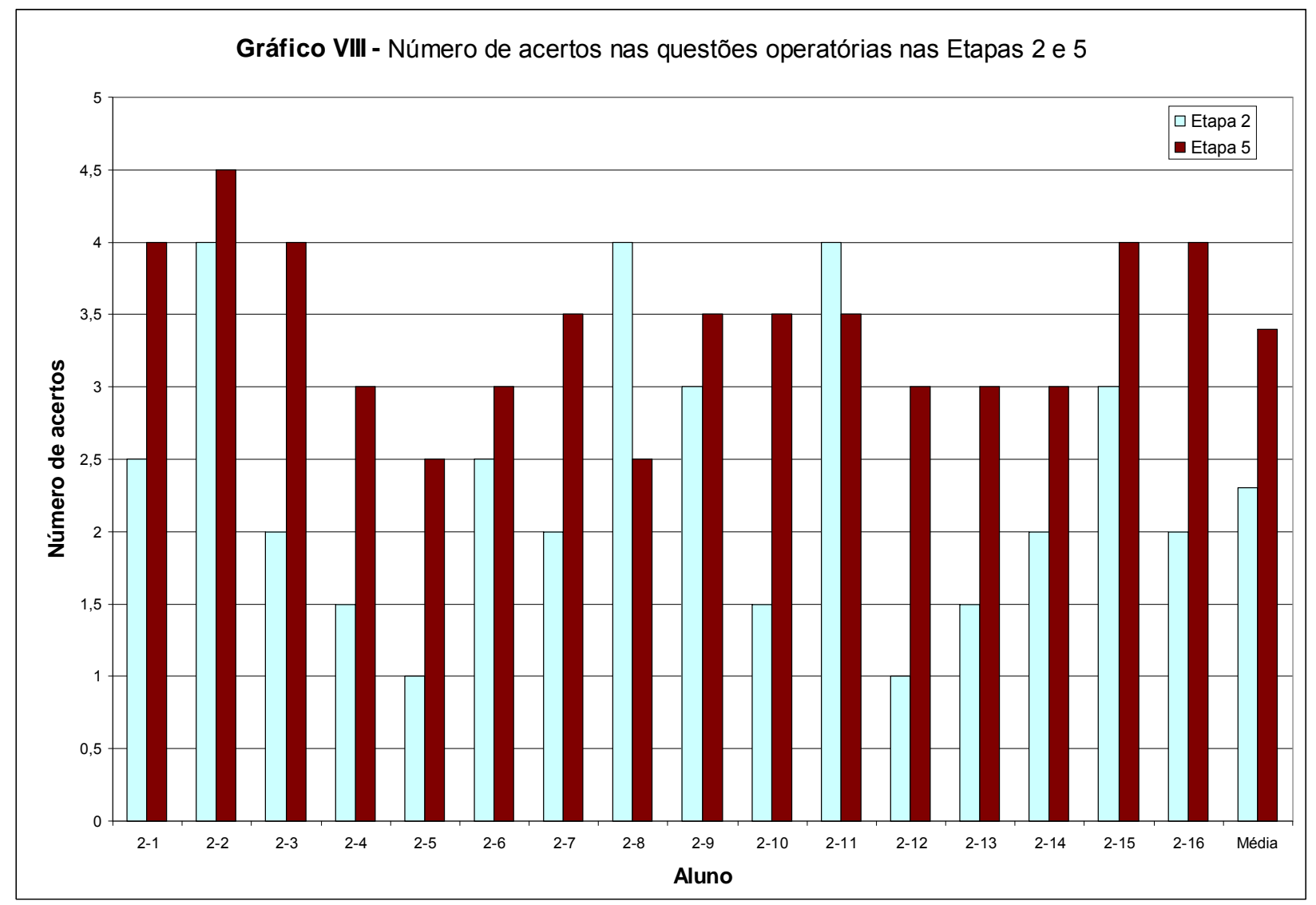

Analisando o Gráfico VIII, verifica-se que dos 16 alunos, 14 (87,5\%) apresentaram uma evolução com relação à resolução das questões operatórias e apenas dois alunos (12,5\%), alunos 2-8 e 2-11, caíram de rendimento. Isso indica que houve um aumento na aprendizagem significativa por parte dos alunos. 


\section{CAPÍTULO 5: CONCLUSÕES E}

\section{CONSIDERAÇÕES FINAIS}

Pela análise dos dados obtidos, verifica-se que a estratégia utilizada apresentou resultados satisfatórios e os objetivos planejados foram atingidos.

Quanto ao procedimento utilizado na coleta de dados, na aplicação de questões não-operatórias e operatórias, na aplicação e discussão dos experimentos de caráter investigativo, é importante salientar que foram feitos objetivando a aprendizagem significativa ou uma melhora dela visando, principalmente, aqueles alunos que possuem maiores dificuldades com a disciplina Química.

A melhora da aprendizagem foi constatada através da aplicação de um questionário três meses após o encerramento do ciclo dos conceitos químicos abordados neste trabalho. Verificou-se, nesta etapa, que tais conceitos químicos ainda estavam pertinentemente bem compreendidos. Isso indica, segundo Ausubel, que grande parte dos alunos teve uma estrutura cognitiva melhorada funcionando como um alicerce para que novas ideias, conceitos, proposições fossem aprendidos significativamente.

O processo se mostrou eficiente e sugere que, se incorporado na prática do professor, pode haver uma melhora no desempenho cognitivo dos estudantes. 


\section{CAPÍTULO 6: REFERÊNCIAS BIBLIOGRÁFICAS}

AUSUBEL, D. P. A Aprendizagem Significativa: A Teoria de David Ausubel. São Paulo: Moraes, 1982.

AUSUBEL, D. P.; NOVAK, J. D.; HANESIAN, H. Psicologia Educacional. Rio de Janeiro: Interamericana, 1980.

BECKER, F. In: HOFFMANN, J. Avaliação mediadora: uma prática em construção da escola à universidade. Porto Alegre: Educação e Realidade, 1993.

BELTRAN, N.O., CISCATO, C.A.M. Química. São Paulo: Cortez, 1991.

BURIASCO, R. L. C. de. Sobre a Resolução de Problemas (I). Nosso Fazer, Ano 1, nº 5. Secretaria Municipal de Educação, Londrina, 1995 a.

CARVALHO, A. M. P. et al. Termodinâmica: Um ensino por investigação. 1a. ed. São Paulo: Universidade de São Paulo - Faculdade de Educação, 1999. v. 1. p. 123.

DELIZOICOV, D. Conhecimentos, tensões e transições. São Paulo: FEUSP, Tese (Doutoramento em Educação) - Universidade de São Paulo, Faculdade de Educação, 1991.

ESTEBAN, M.T. A avaliação no cotidiano escolar. In: Avaliação: uma prática em busca de novos sentidos. Rio de Janeiro: DP\& A, 1999. p. 7- 28.

FREIRE, P. Pedagogia do oprimido. Rio de Janeiro: Paz e Terra, 1987

HADJI, C. A avaliação desmistificada. Porto Alegre: Artmed, 2001. 
HADJI, C. A avaliação regras do jogo: das intenções aos instrumentos. 4. ed. Portugal: Porto Editora, 1994.

HODSON, D. Journal of Curriculum Studies, 28, p. 115-130, 1996.

HOFFMANN, Jussara. Avaliação mediadora: uma prática em construção da pré-escola à universidade. 20 ed. Porto Alegre: Editora Mediação, 2003.

JUSTI, R. e RUAS, R. Aprendizagem de Química. Química Nova na Escola, n. 5, p. 2427, 1997.

LDB - LEI DE DIRETRIZES E BASES DA EDUCAÇÃO NACIONAL, Lei Nº 9394, Disponível em http://portal.mec.gov.br/seed/arquivos/pdf/tvescola/leis/lein9394.pdf. Acesso em: 18 Ago 2009.

LUCKESI, C. Avaliação da aprendizagem escolar: estudos e proposições. São Paulo: Cortez, 1997.

MACHADO, A.H. e MOURA, A.L.A. Linguagem no ensino de química. Química Nova na Escola, n. 2, p. 27-30, 1995.

MACHADO, A.H. Pensando e falando sobre fenômenos químicos. Química Nova na Escola, n. 12, p. 38-42, 2000.

MACHADO, P.F.L. e MOL, G.S. Experimentando Química com segurança. Revista Química Nova na Escola, № 27, Fevereiro de 2008, páginas 57-60.

MALDANER, O.A. A formação inicial e continuada de professores de Química. ljuí: Ed. Unijuí, 2003. 
MATTHEWS, M.R. Vino viejo en botellas nuevas: Un problema com la epistemologia constructivista. Enseñanza de lãs Ciencias, v. 12, p. 79-88, 1994.

PCNEM 1999 - PARÂMETROS CURRICULARES NACIONAIS PARA O ENSINO MÉDIO. Disponível em http://portal.mec.gov.br/seb/arquivos/pdf/CienciasNatureza.pdf. Acesso em: 18 Ago 2009.

PCNEM 2008 - PARÂMETROS CURRICULARES NACIONAIS PARA O ENSINO MÉDIO. Disponível em http://portal.mec.gov.br/seb/arquivos/pdf/ciencian.pdf. Acesso em: 18 Dez 2010.

PERRENOUD, P. Avaliação: da excelência à regulação das aprendizagens - entre duas lógicas. Porto Alegre: Artes Médicas, 1999.

PIAGET, J. e INHELDER, B. La psychologie de l'enfant. Paris, Presses Universitaires de France, 1966.

PISA - PROGRAMA INTERNACIONAL DE AVALIAÇÃO DE ALUNOS, Resultados Nacionais, 2009. Disponível em http://www.inep.gov.br/internacional/novo/PISA/resultados.htm. Acesso em: 25 Dez 2010.

PONTE, J. P.; BOAVIDA, A.; GRAÇA, M.; ABRANTES, P. Propósitos e funções da avaliação. In: Didáctica da Matemática. Lisboa: DES do ME, 1997.

ROMANELLI, L.I. O papel mediador do professor no processo ensino-aprendizagem do conceito átomo. Química Nova na Escola, n. 3, p. 27-31, 1996.

RONCA, A. C. e TERZI, C. A., A aula operatória e a construção do conhecimento. São Paulo: EDESPLAN, 1995. 
WATSON, R.; PRIETO, T.; DILLION, J. S. "The Effect of Practical Work on Students Understanding of Combustion". Journal of Research in Science Teaching. 32 (5), p. 487-502, 1995.

ZANON, L. B.; SILVA, L. H. A. "A Experimentação no Ensino de Ciências". In: Roseli P. Schnetzler e Rosália M. R. Aragão (Org.). Ensino de Ciências: fundamentos e abordagens. Campinas: CAPES / UNIMEP, 2000, p. 120-153.

ZOLLER, U., DORI, Y.; LUBEZKY, A. Algorithmic and LOCS and. HOCS (Chemistry) Exam Questions: Performance and Attitudes of College Students. International Journal of Science Education. 24 (2), p.185-203, 2002. 


\section{ANEXOS}

\section{ANEXO A: Roteiro Experimental do 1ํano (Separação de misturas)}

\section{EXPERIMENTO - COMO SEPARAR???}

I. Objetivo: Propor um procedimento para separar os componentes da seguinte mistura: cloreto de sódio ( $\mathrm{NaCl}$, principal componente do sal de cozinha), carbonato de cálcio $\left(\mathrm{CaCO}_{3}\right.$, principal componente do mármore), grãos de feijão, areia, grampos de grampeador.

\section{Materiais:}

- 1 Espátula

- 2 Papéis de filtro

- 1 Cápsula de porcelana - 1 Bastão de vidro

- 1 Lamparina

- 1 Funil

- 1 peneira

- Areia

- Grampos de grampeador

\section{Reagentes:}

- Cloreto de sódio, $\mathrm{NaCl}$ (sal de cozinha)

- Carbonato de cálcio, $\mathrm{CaCO}_{3}$ (mármore)

- Água

- Ácido clorídrico diluído, $\mathrm{HCl}$

\section{Procedimento Experimental:}

Separe os componentes da mistura formada, escolhendo os processos mais econômicos possíveis (lembre-se de que o cloreto de sódio é solúvel e o carbonato de cálcio é insolúvel em água). DETALHE IMPORTANTE: nesse caso, é importante 
separar o cloreto de sódio, areia, grãos de feijão e grampos de grampeador. O carbonato de cálcio poderá ser descartado!!!

\section{Resultados:}

Descreva no quadro abaixo todos os processos utilizados para separar os componentes da mistura cloreto de sódio $(\mathrm{NaCl}$, principal componente do sal de cozinha), carbonato de cálcio $\left(\mathrm{CaCO}_{3}\right.$, principal componente do mármore), grãos de feijão, areia, grampos de grampeador. 
Anote no quadro abaixo todas as observações que achar pertinentes:

\section{Questões:}

01. Descreva detalhadamente como você separou a mistura de cloreto de sódio $(\mathrm{NaCl}$, principal componente do sal de cozinha), carbonato de cálcio $\left(\mathrm{CaCO}_{3}\right.$, principal componente do mármore), grãos de feijão, areia, grampos de grampeador. Quais métodos de separação você utilizou? Em que propriedade se baseia cada um desses métodos?

02. Por que a água se separa do sal de cozinha por simples evaporação?

03. (UNICAMP) Uma mistura sólida é constituída de cloreto de prata, cloreto de sódio e cloreto plumboso. Observe a solubilidade desses sais em água:

\section{Sais}

Cloreto de prata

Cloreto de sódio

Cloreto plumboso
Água fria

Insolúvel

Solúvel

Insolúvel
Água quente

Insolúvel

Solúvel

Solúvel

Baseando-se nesses dados, esquematize uma separação desses sais que constituem a mistura.

BOA EXPERIÊNCIA!!! 


\section{ANEXO B: Roteiro Experimental do $2^{\circ}$ ano (Cinética Química)}

\section{EXPERIMENTO - FATORES QUE INFLUENCIAM NA RAPIDEZ DE UMA TRANSFORMAÇÃO QUÍMICA}

I. Objetivo: Propor procedimentos para verificar como a temperatura, a superfície de contato, a concentração e o catalisador influenciam na rapidez de uma transformação química.

\section{Materiais:}

- 3 béqueres de $100 \mathrm{~mL} \quad$ - Papel indicador de $\mathrm{pH}$

- 1 espátula - Cronômetro

- Almofariz e pistilo

\section{Reagentes:}

- Água à temperatura ambiente

- Água gelada

- Água quente

- Água oxigenada a 10 volumes
- Comprimidos de Sonrisal ${ }^{\circledR}$

- Solução de $\mathrm{HCl} 1 \mathrm{~mol} / \mathrm{L}$ e $2 \mathrm{~mol} / \mathrm{L}$

- Magnésio metálico em raspas

- Fígado cru de boi

\section{Procedimento Experimental:}

PARTE 1: Influência da temperatura:

Utilizando comprimidos de Sonrisal e água, proponha um método que possibilite verificar qual a influência da temperatura na rapidez de uma transformação química.

\section{PARTE 2: Influência da superfície de contato}

Utilizando comprimidos de Sonrisal e água, proponha um método que possibilite verificar qual a influência da superfície de contato na rapidez de uma transformação química. 
PARTE 3: Influência da concentração do $\mathrm{HCl}$ em uma reação com magnésio metálico Utilizando raspas de magnésio metálico e soluções aquosas de $\mathrm{HCl}$ de concentrações 1 $\mathrm{mol} / \mathrm{L}$ e $2 \mathrm{~mol} / \mathrm{L}$, proponha um método que possibilite verificar qual a influência da concentração na rapidez de uma transformação química.

PARTE 4: Influência do catalisador catalase na velocidade de decomposição da água oxigenada

a) Coloque água oxigenada em 1 béquer até a metade do seu volume.

b) Coloque 5 cubos de fígado cru. Observe atentamente a liberação de bolhas que ocorre no béquer. Anote suas observações.

\section{Resultados:}

PARTE 1: Influência da temperatura:

Resultados observados:

PARTE 2: Influência da superfície de contato

Resultados observados: 
PARTE 3: Influência da concentração do $\mathrm{HCl}$ em uma reação com magnésio metálico

Resultados observados:

PARTE 4: Influência do catalisador catalase na velocidade de decomposição da água oxigenada

Resultados observados:

\section{Questões:}

01. De acordo com a parte 1 , como a temperatura influencia na rapidez de uma transformação química? Justifique esse fato.

02. De acordo com a parte 2, em que situação a reação ocorreu com maior rapidez? Justifique esse fato.

03. De acordo com a parte 4 , em que situação a reação se processou mais rapidamente? Justifique esse fato.

04. Na parte 4, existe alguma relação entre o tempo de reação e a concentração do $\mathrm{HCl}$ ? Justifique.

05. Sabendo que a água oxigenada é uma solução aquosa de peróxido de hidrogênio, $\mathrm{H}_{2} \mathrm{O}_{2}$, e que o fígado de boi contém catalase, uma enzima (age como catalisador) que aumenta a rapidez de uma transformação química (nesse caso, aumenta a rapidez da reação de decomposição do $\mathrm{H}_{2} \mathrm{O}_{2}$ ), responda: 
a) Qual a reação de decomposição que ocorre com a substância $\mathrm{H}_{2} \mathrm{O}_{2}$ ? Equacione essa reação.

b) Essa reação ocorreria sem a presença da catalase? Se sim, seria mais lento ou mais rápido? Justifique.

c) Qual o gás constituinte das bolhas desta parte do experimento?

05. Uma indústria que tem sua produção baseada em reações químicas investiu grandes somas para instalar sistemas de aquecimento. Que vantagens deve trazer essa instalação?

06. (UNICAMP) Amostras de magnésio foram colocadas em soluções de ácido clorídrico a diversas concentrações e temperaturas, havendo total dissolução do metal e desprendimento de hidrogênio gasoso. Observaram-se os seguintes resultados:

\section{Número da amostra}

1

2

3

4
Massa de magnésio dissolvida em gramas

2,0

0,4

0,4

0,5
Tempo para dissolver

(minutos)

10,0

2,0

1,0

1,0

a) em qual caso a velocidade média da reação foi maior? Justifique.

b) em qual caso desprendeu-se maior quantidade de hidrogênio? Justifique. 


\section{ANEXO C: Exercícios de caráter não-operatório (Etapa 1)}

\section{$1^{\circ}$ ano (Separação de Misturas)}

1. (U. F. Santa Maria - RS) Num acampamento, todo o sal de cozinha foi derramado na areia. As pessoas recuperaram o sal realizando, sucessivamente, as operações de:
a) dissolução, filtração, evaporação.
b) fusão, decantação e sublimação.
c) liquefação, filtração e vaporização.
d) adição de água e destilação.
e) diluição, sedimentação e vaporização.

2. (UFRGS) Qual dos métodos de separação seguintes se baseia na diferença de densidade?
a) decantação
b) destilação fracionada
c) peneiração
d) cristalização
e) sublimação

3. (UFPE) Qual dos seguintes processos pode ser usado para extrair sal de cozinha da água do mar?
a) Filtração
b) Decantação
c) Eliminação da água, por vaporização
d) Diluição
e) Eletroforese

4. O que é filtração e que tipo de mistura ele permite separar? Cite dois exemplos de mistura que podem ser separados por este método. 
5. Para separar limalha de ferro de sal de cozinha, pode-se utilizar o método da:
a) separação magnética
b) catação
c) flotação
d) filtração
e) levigação

\section{$2^{\circ}$ ano (Cinética Química)}

1. Qual é a influência da superfície de contato na rapidez de uma reação química?

2. O que é a energia de ativação?

3. Por que o aumento da temperatura aumenta a rapidez de uma reação química?

4. Explique como a concentração pode alterar a rapidez de uma reação química.

5. Catalisador é:

a) uma substância que não possui participação na reação.

b) sinônimo de luz.

c) sinônimo de calor.

d) uma substância que acelera a reação e, no final, desaparece do sistema.

e) uma substância que acelera a reação e, no final, apresenta massa constante. 


\section{ANEXO D: Exercícios de caráter operatório pré-experimento (antes da reconstrução da prática avaliativa) e reaplicados após três meses do término da abordagem dos conceitos de Separação de Misturas - Etapas 2 e 5}

\section{$1^{\circ}$ ano (Separação de Misturas)}

1. (UNICAMP) Em um acampamento, um estudante deixou cair na areia todo o sal de cozinha disponível. Entretanto, tendo conhecimento sobre separação de misturas, conseguiu recuperar todo o sal. Que operações este estudante pode ter realizado? Explique.

2. (UNICAMP) Em uma república estudantil, um dos moradores deixou cair óleo combustível no recipiente que continha sal de cozinha. Considerando que o sal não é solúvel no óleo, mas solúvel em água, como será possível recuperar o sal e o óleo, deixando-os novamente em condições de uso?

3. Grãos de polietileno $\left(\mathrm{d}=0,93 \mathrm{~g} / \mathrm{cm}^{3}\right)$, plástico muito utilizado em embalagens, devido à sua baixa reatividade, podem ser separados de grãos de PVC $\left(d=1,05 \mathrm{~g} / \mathrm{cm}^{3}\right)$, plástico muito utilizado em tubos, devido à sua resistência mecânica e facilidade de moldagem, quando misturados, por simples adição de água $\left(d=1,00 \mathrm{~g} / \mathrm{cm}^{3}\right)$. Explique esse fato.

4. A figura a seguir mostra o esquema de um processo usado para a obtenção de água potável a partir da água salobra (que contém alta concentração de sais). Este "aparelho" improvisado é usado em regiões desérticas da Austrália. 


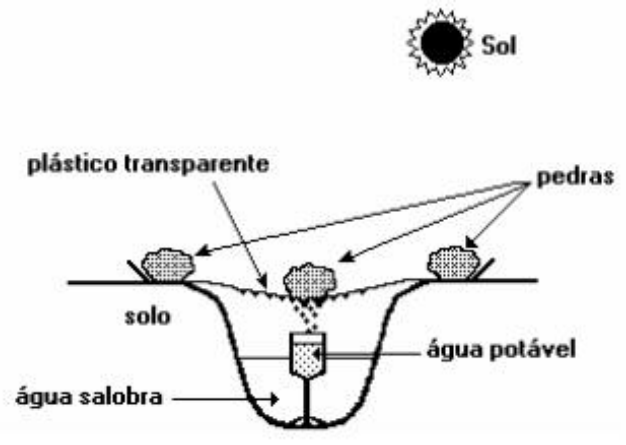

a) Que mudanças de estado ocorrem com a água, dentro do "aparelho"?

b) Com base no esquema, explique como obter a água pura.

5. Uma técnica usada para limpar aves cobertas por petróleo consiste em pulverizá-las com limalha de ferro. Proponha uma explicação para isso.

\section{2o ano (Cinética Química)}

1. Juscelino está prestes a viajar para a Europa. Para se despedir dos amigos, organizou uma "churrascada" em sua casa na hora do almoço (12h00). Os amigos iam chegando aos poucos e Juscelino, muito receptivo, falava sobre seus planos para o futuro. Eram $16 \mathrm{~h} 00$ e Juscelino, muito distraído, havia se esquecido completamente do churrasco. Seus amigos começaram a reclamar dizendo que estavam com muita fome e pediram para que Juscelino assasse o churrasco o mais breve possível.

Apesar de distraído, Juscelino é muito esperto: colocou pequenos pedaços de carvão (ao invés de pedaços grandes) e ficou abanando a brasa frequentemente. Assim, o churrasco ficou pronto rapidamente.

Por que colocar pequenos pedaços de carvão faz com que o churrasco asse mais rápido do que com grandes pedaços? Justifique claramente com base na Cinética Química.

2. Lindomar, um dos milhares de jogadores de futebol amador do país, estava praticando o esporte em um campo de várzea até que, sem querer, tropeça em uma pedra e acaba ferindo gravemente seu joelho com bastante sangramento. $O$ médico da 
equipe entra em campo e realiza os primeiros socorros, limpando o local da ferida com água oxigenada, $\mathrm{H}_{2} \mathrm{O}_{2}$, e observando um borbulhamento.

a) O que seria esse borbulhamento? Justifique através da equação química correspondente. Há alguma relação dessa reação com a energia de ativação?

b) Muitas pessoas costumam dizer que a água oxigenada "ferve" sobre a ferida. $\mathrm{O}$ termo "ferver" é correto? Justifique.

3. Uma indústria que tem sua produção baseada em reações químicas investiu grandes somas para instalar sistemas de aquecimento. Que vantagens deve trazer essa instalação? Explique claramente com base na Cinética Química.

4. (UFRGS) O carvão é um combustível constituído de uma mistura de substâncias ricas em carbono. A situação em que a forma de apresentação do combustível e do comburente e a temperatura utilizada favorecerão a combustão do carbono com maior rapidez é:

\begin{tabular}{l|l|c|c|}
\cline { 2 - 4 } & Combustível & Comburente & Temperatura \\
\cline { 2 - 4 } a) & Carvão em pedaços & Ar atmosférico & $0^{\circ} \mathrm{C}$ \\
\cline { 2 - 4 } b) & Carvão pulverizado & Ar atmosférico & $30^{\circ} \mathrm{C}$ \\
\cline { 2 - 4 } c) & Carvão em pedaços & Oxigênio puro & $20^{\circ} \mathrm{C}$ \\
\cline { 2 - 4 } d) & Carvão pulverizado & Oxigênio puro & $100^{\circ} \mathrm{C}$ \\
\cline { 2 - 4 } e) & Carvão em pedaços & Oxigênio puro & $50^{\circ} \mathrm{C}$ \\
\cline { 2 - 4 } & &
\end{tabular}

5. (FUVEST) Para remover uma mancha de um prato de porcelana, fez-se o seguinte: cobriu-se a mancha com meio copo de água fria, adicionaram-se algumas gotas de vinagre e deixou-se por uma noite. No dia seguinte, a mancha havia clareado levemente. Usando apenas água e vinagre, sugira duas alterações no procedimento, de tal modo que a remoção da mancha possa ocorrer em menor tempo. Justifique cada uma das alterações propostas. 


\section{ANEXO E: Exercícios de caráter operatório pós-experimento (após a reconstrução da prática avaliativa) - Etapa 4}

\section{1 ano (Separação de Misturas)}

1. Suponha que você se deparou com uma mistura de areia, sal e limalha de ferro. Como você faria para separar as substâncias dessa mistura? Descreva com detalhe a sequência de etapas do processo de separação.

2. Uma mistura sólida é constituída de cloreto de prata, cloreto de sódio e cloreto de chumbo. A solubilidade dessas substâncias, em água, está resumida na tabela abaixo. Baseando-se nestes dados de solubilidade, esquematize uma separação dessas três substâncias que constituem a mistura. Dado:

\section{Substância}

Cloreto de prata

Cloreto de sódio

Cloreto de chumbo
Água fria

Insolúvel

Solúvel

Insolúvel

\section{Água quente}

Insolúvel

Solúvel

Solúvel

Observação:

- Solúvel = que se dissolve (por exemplo: o cloreto de sódio é solúvel em água fria, ou seja, o cloreto de sódio se dissolve em água fria).

- Insolúvel = que não se dissolve (por exemplo: o cloreto de prata é insolúvel em água fria, ou seja, o cloreto de prata não se dissolve em água fria).

3. (FUVEST) Em uma indústria, um operário misturou, inadvertidamente, polietileno (PE), policloreto de vinila (PVC) e poliestireno (PS), limpos e moídos. Para recuperar cada um desses polímeros, utilizou o seguinte método de separação: jogou a mistura em um tanque contendo água (densidade $=1,00 \mathrm{~g} / \mathrm{cm}^{3}$ ), separando, então, a fração que flutuou (fração A) daquela que foi ao fundo (fração B). A seguir, recolheu a fração $B$, secou-a e jogou-a em outro tanque contendo solução salina (densidade $=1,10$ $\mathrm{g} / \mathrm{cm}^{3}$ ), separando o material que flutuou (fração C) daquela que afundou (fração $D$ ). 
Polímero

Polietileno (PE)

Poliestireno (PS)

Policloreto de vinila (PVC)

As frações $A, C$ e $D$ eram, respectivamente:
a) PE, PS e PVC
b) PS, PE e PVC
c) PVC, PS e PE
d) PS, PVC e PE
e) PE, PVC, PS

Densidade $\left(\mathrm{g} / \mathrm{cm}^{3}\right)$ (na temperatura de trabalho)

0,91 a 0,98

1,04 a 1,06

1,35 a 1,42

4. (UNICAMP) Considere as seguintes misturas:

I) areia e água

II) álcool (etanol) e água

III) sal de cozinha $(\mathrm{NaCl})$ e água, neste caso uma mistura homogênea.

Cada uma dessas misturas foi submetida a uma filtração em um funil com papel e, em seguida, o líquido resultante (filtrado) foi aquecido até sua total evaporação. Pergunta-se:

a) Qual mistura deixou um resíduo sólido no papel após a filtração? O que era esse resíduo?

b) Em qual caso apareceu um resíduo sólido após a evaporação do líquido? O que era esse resíduo?

5. (UNITAU) Uma maneira rápida e correta de separar uma mistura com ferro, sal de cozinha e arroz é, na sequência:

a) filtrar, aproximar um ímã, adicionar água e destilar.

b) adicionar água e destilar.

c) aproximar um ímã, adicionar água, filtrar e destilar.

d) destilar, adicionar água, aproximar um ímã.

e) impossível de separá-la 


\section{2ำ ano (Cinética Química)}

1. Alguns medicamentos são apresentados na forma de comprimidos que, quando ingeridos, se dissolvem lentamente no líquido presente no tubo digestório, garantindo um efeito prolongado no organismo. Contudo, algumas pessoas, por conta própria, amassam o comprimido antes de tomá-lo. Que inconveniente existe nesse procedimento?

2. A água oxigenada é uma solução aquosa de $\mathrm{H}_{2} \mathrm{O}_{2}$, que pode se decompor:

$$
\mathrm{H}_{2} \mathrm{O}_{2} \rightarrow \mathrm{H}_{2} \mathrm{O}+1 / 2 \mathrm{O}_{2}
$$

Assinale a alternativa que enumera as condições ideais para evitar essa decomposição:

\begin{tabular}{l|c|c|c|} 
a) & Escuro & $40^{\circ} \mathrm{C}$ & Sem catalisador \\
\cline { 2 - 4 } b) & Luz & $10^{\circ} \mathrm{C}$ & Com catalisador \\
\cline { 2 - 4 } c) & Luz & $40^{\circ} \mathrm{C}$ & Com catalisador \\
d) & Escuro & $10^{\circ} \mathrm{C}$ & Com catalisador \\
\cline { 2 - 4 } e) & Escuro & $10^{\circ} \mathrm{C}$ & Sem catalisador \\
\cline { 2 - 4 } & &
\end{tabular}

3. Para evitar a deterioração dos alimentos, muitas embalagens são hermeticamente fechadas sob nitrogênio ou sob uma quantidade de ar muito pequena. Além disso, nos rótulos de diversos produtos alimentícios embalados dessa forma encontram-se, freqüentemente, informações como:

- Validade: 6 meses da data de fabricação se não for aberto.

- Após aberto, deve ser guardado, de preferência, em geladeira e consumido em até 5 dias.

- Contém antioxidante.

Pode-se dizer que o antioxidante é uma substância colocada no produto alimentício que reage "rapidamente" com oxigênio.

Com base nas informações anteriores, responda, em termos químicos: Por que a recomendação de guardar o alimento em geladeira depois de aberto? 
4. O metal ferro reage com uma solução aquosa de $\mathrm{HCl}$, originando gás hidrogênio e cloreto de ferro II. Assinale a alternativa que indica a reação mais rápida entre o ferro e uma solução de $\mathrm{HCl} 1,0 \mathrm{~mol} / \mathrm{L}$ :

$$
\mathrm{Fe}_{(\mathrm{s})}+2 \mathrm{HCl}_{(\mathrm{aq})} \rightarrow \mathrm{FeCl}_{2(\mathrm{aq})}+\mathrm{H}_{2(\mathrm{aq})}
$$
a) um prego de ferro, a $25^{\circ} \mathrm{C}$.
b) um prego de ferro, a $40^{\circ} \mathrm{C}$.
c) ferro em pó, a $40^{\circ} \mathrm{C}$.
d) ferro, a $25^{\circ} \mathrm{C}$.
e) Essa reação não depende da superfície de contato ou da temperatura.

5. Para remover uma mancha de um objeto de porcelana, fez-se o seguinte: cobriu-se a mancha com meio copo de álcool, adicionaram-se algumas gotas de sumo de limão e deixou-se por uma noite. No dia seguinte, a mancha havia clareado levemente. Usando apenas álcool e sumo de limão, sugira duas alterações no procedimento, de tal modo que a remoção da mancha possa ocorrer em menor tempo. Justifique cada uma das alterações propostas. 